\title{
Article \\ Genetic and Biochemical Characterizations of aLhr1 Helicase in the Thermophilic Crenarchaeon Sulfolobus acidocaldarius
}

\author{
Shoji Suzuki ${ }^{1}{ }^{\circledR}$, Norio Kurosawa ${ }^{2}$ (), Takeshi Yamagami ${ }^{1}$ (), Shunsuke Matsumoto ${ }^{1}$, Tomoyuki Numata ${ }^{1}$, \\ Sonoko Ishino ${ }^{1, *}$ and Yoshizumi Ishino ${ }^{1, *}$ \\ 1 Department of Bioscience and Biotechnology, Graduate School of Bioresource and Bioenvironmental Sciences, \\ Kyushu University, Fukuoka 819-0395, Japan; s.suzukie@gmail.com (S.S.); \\ yamagami@agr.kyushu-u.ac.jp (T.Y.); smatsumoto@agr.kyushu-u.ac.jp (S.M.); \\ tomoyuki.numata94@agr.kyushu-u.ac.jp (T.N.) \\ 2 Department of Science and Engineering for Sustainable Development, Faculty of Science and Engineering, \\ Soka University, Hachioji 192-8577, Japan; kurosawa@soka.ac.jp \\ * Correspondence: ishino@agr.kyushu-u.ac.jp (S.I.); sonoko@agr.kyushu-u.ac.jp (Y.I.); \\ Tel.: +81-92-802-4715 (S.I.); +81-92-802-4714 (Y.I.); Fax: +81-92-802-4696 (S.I. \& Y.I.)
}

Citation: Suzuki, S.; Kurosawa, N.; Yamagami, T.; Matsumoto, S.;

Numata, T.; Ishino, S.; Ishino, Y.

Genetic and Biochemical

Characterizations of aLhr1 Helicase in the Thermophilic Crenarchaeon Sulfolobus acidocaldarius. Catalysts 2022, 12, 34. https://doi.org/ $10.3390 /$ catal12010034

Academic Editors:

Giuseppe Perugino, Isaac Cann,

Anna Valenti and Cinzia Verde

Received: 1 December 2021

Accepted: 27 December 2021

Published: 29 December 2021

Publisher's Note: MDPI stays neutral with regard to jurisdictional claims in published maps and institutional affiliations.

Copyright: (c) 2021 by the authors. Licensee MDPI, Basel, Switzerland. This article is an open access article distributed under the terms and conditions of the Creative Commons Attribution (CC BY) license (https:// creativecommons.org/licenses/by/ $4.0 /)$.

\begin{abstract}
Homologous recombination (HR) refers to the process of information exchange between homologous DNA duplexes and is composed of four main steps: end resection, strand invasion and formation of a Holliday junction ( $\mathrm{HJ}$ ), branch migration, and resolution of the HJ. Within each step of HR in Archaea, the helicase-promoting branch migration is not fully understood. Previous biochemical studies identified three candidates for archaeal helicase promoting branch migration in vitro: Hjm/Hel308, PINA, and archaeal long helicase related (aLhr) 2. However, there is no direct evidence of their involvement in HR in vivo. Here, we identified a novel helicase encoded by Saci_0814, isolated from the thermophilic crenarchaeon Sulfolobus acidocaldarius; the helicase dissociated a synthetic HJ. Notably, HR frequency in the Saci_0814-deleted strain was lower than that of the parent strain (5-fold decrease), indicating that Saci_0814 may be involved in HR in vivo. Saci_0814 is classified as an aLhr1 under superfamily 2 helicases; its homologs are conserved among Archaea. Purified protein produced in Escherichia coli showed branch migration activity in vitro. Based on both genetic and biochemical evidence, we suggest that aLhr1 is involved in HR and may function as a branch migration helicase in S. acidocaldarius.
\end{abstract}

Keywords: archaea; homologous recombination; branch migration helicase; hyperthermophile; Holliday junction

\section{Introduction}

Genomic DNA, which encodes genetic information, is always damaged by endogenous and exogenous factors, and the frequency of damage is accelerated by two to three orders of magnitude at high temperatures [1]. Hyperthermophiles are microorganisms that flourish in hot environments (above $80^{\circ} \mathrm{C}$ ) [2]. The topic of how hyperthermophiles consistently maintain their genome integrity under extreme environments has been discussed in recent years, and the idea that hyperthermophiles efficiently repair DNA damage occurring at elevated levels has been proposed. Thus, studies to elucidate DNA repair mechanisms in hyperthermophiles are necessary for understanding the mechanisms underlying the maintenance of genetic information in living cells. In particular, most hyperthermophiles belong to the Archaea domain [2]; thus, the DNA repair mechanisms in archaeal cells have been studied (reviewed in [3-10]). However, these mechanisms remain to be completely elucidated, and further analyses are required.

In several DNA repair pathways, homologous recombination (HR) is important for both stalled-replication fork and double-strand break repairs in hyperthermophilic Archaea (HA). It serves as the major DNA repair pathway for the removal of a wide variety of DNA 
lesions and is unusually efficient and reliable in comparison with that in other organisms [7]. The HR process is generally composed of four steps, and some of the proteins have been predicted to work for each step in HA [9]. The first step is end resection to produce a $3^{\prime}$-single-stranded DNA (ssDNA) by the Rad50-Mre11-HerA-NurA complex. In the second step, the $3^{\prime}$-ssDNA is used for strand invasion and formation of a Holliday junction (HJ), which is catalyzed by recombinase RadA with assistance from accessory proteins. In the third step, branch migration of the HJs is possibly catalyzed by candidates for branch migration helicase. Finally, HJ is resolved by the HJ-specific endonuclease Hjc and/or its paralog Hje in some Archaea.

To date, three proteins, namely, Holliday junction migration (Hjm)/Hel308, PilT N-terminal-(PIN)-domain-containing ATPase (PINA), and archaeal long helicase related (aLhr) 2, have been characterized as candidates for branch migration helicase because these helicases show branch migration activity in vitro. Branch migration activity against a synthetic $\mathrm{HJ}$ is defined as the ability to dissociate a synthetic $\mathrm{HJ}$ to half junctions (splayed DNA). As the first report of a candidate for branch migration helicase, Hjm from the hyperthermophilic euryarchaeon Pyrococcus furiosus has been characterized in vitro, given that it shows branch migration activity against a synthetic $\mathrm{HJ}$ and plasmid-based recombinasemediated recombination intermediate [11]. The Hjm homolog (Hel308) from the euryarchaeon Methanothermobacter thermautotrophicus also has a structure-specific helicase activity [12]. Genetic complementation experiments using the E. coli dnaE mutant strain demonstrated that the role of Hjm in P. furiosus and Hel308 of M. thermautotrophicus was identical to that of the RecQ helicase, suggesting that Hjm/Hel308 may be involved in the repair of stalled replication forks [12,13]. Hjm/Hel308 from the crenarchaeon Sulfolobus tokodaii (reclassified as Sulfurisphaera tokodaii [14]) [15] also have unwinding activity against a synthetic HJ (without product assignment) and a chicken-foot structure produced by replication fork regression, respectively. Guy and Bolt demonstrated that the UV sensitivity of the $\triangle r u v A B C$ or $\triangle r u v A B C / \triangle r e c G$ mutant $E$. coli cells increased when the gene for $M$. thermautotrophicus Hel308 was expressed in these strains, suggesting that Hel308 interfered with another repair process independently [12].

The second candidate is PINA, which was originally identified as a novel ATPase associated with $\mathrm{Hjc}$, the $\mathrm{HJ}$ resolvase, from the hyperthermophilic crenarchaeon Saccharolobus (formerly Sulfolobus) islandicus [16]. PINA forms a hexameric ring, promotes branch migration of a synthetic HJ in vitro, as observed for the bacterial branch migration helicase RuvB [17]. This report also proposed a mechanism for branch migration by PINA, and further analysis proposed mechanisms of stalled replication fork repair based on the functions of Hjm, PINA, and Hjc [18]. Based on these results, S. islandicus PINA appears to be a helicase involved in the $\mathrm{HJ}$ branch migration process. However, its physiological role in vivo needs to be further characterized.

The third candidate was the protein named long helicase related (Lhr), which was originally identified and characterized in bacteria $[19,20]$. The first characterized aLhr is SSO0112 from Saccharolobus solfataricus [21], which was later identified again as Saci_1500 from Sulfolobus acidocaldarius [22]. This helicase can unwind a synthetic HJ, thereby producing ssDNA, but it cannot produce half junctions. The mutant strain with deletion of the corresponding gene is more sensitive to UV light but not to hydroxyurea and methyl methanesulfonate (MMS) [22], suggesting that this group of helicases function in some specific pathway including the UV damage repair in Sulfolobales. The recombination frequencies were not different between the wild type and mutant strains, suggesting that the function of this helicase is not important for the HR process in vivo. More recent studies showed that Mt_1802, from $M$. thermautotrophicus, catalyzes the branch migration of a synthetic HJ and compensates for the loss of RecQ function in E. coli cells. These properties are similar to those of Hjm/Hel308 [23]. A comprehensive phylogenetic analysis of the superfamily 2 (SF2) helicases in living organisms proposed that aLhrs can be divided into two groups: Lhr1 and Lhr2, from which the above aLhrs were classified as Lhr1 [24]. However, a recent report also describing a comprehensive phylogenetic analysis of the 
SF2 helicases showed that the aLhrs are divided into four phylogenetically distinct groups, namely, aLhr1, aLhr2, aLhr3, and aLhr-like [25]. Archaeal Lhrs share a conserved structure containing RecA1, RecA2, and winged helix domains, but domain 4 is conserved only in aLhr1 and aLhr2. aLhr3 is characterized by a highly deteriorated domain 4 [25]. The names for aLhr1 and aLhr2 in this report were different from those described in a previous one [24].

As per the published reports, the exact functions of these candidate helicases in cells remain unclear. Thus, to expand our knowledge about the HR process in Archaea, it is important to determine which helicase is primarily involved in the branch migration process. ssDNA-binding proteins, designated as SSB in Bacteria and Crenarchaea, or replication protein A (RPA) in Eukarya and Euryarchaea, specifically bind ssDNA without sequencespecificity via oligonucleotide-binding folds (OB-fold) [26-28]. This protein is universally distributed in cellular organisms with some exceptions [29] and plays essential roles in DNA replication, recombination, and repair [30-32]. It is known to be involved in HR in cellular life, and the functional mechanism is considered to bind to the ssDNA region of $3^{\prime}$-overhang DNA produced by the end resection, and protects the formation of a secondary structure of ssDNA, thereby promoting strand exchange catalyzed by the recombinase in vitro [33-36]. As another function of crenarchaeal SSB in HR, Rolfsmeier and Haseltine discussed the possibility that SSB incorporated a number of likely recombination mediators in the presynaptic step before the strand invasion of HR [37]. The role of physical and functional protein interactions involving SSBs in HR remains unresolved and argued the possibility that SSB bridged between DNA and such proteins [i.e., NurA and RadA [37,38]. As SSB of S. solfataricus destabilized double-stranded DNA (dsDNA)-containing lesions and possibly interacted with other proteins, Cubeddu and White hypothesized that SSB recruited proteins to damage sites via protein interaction [39]. Based on these concepts, we questioned whether SSB acts as a scaffold protein to localize proteins to HR sites via protein interaction. A previous pull-down experiment with a biotin-ssDNA saturated with SSB from the $S$. solfataricus cell extract demonstrated that some unknown proteins with a helicase-like sequence were co-purified with an ssDNA-SSB complex, suggesting that these helicase-like proteins interacted with SSB [39]. Therefore, it would be suitable to investigate the activity and function of these proteins.

In this study, based on the concepts described above, we focused on a protein Saci_0814, which is the homolog of the above helicase-like protein in S. acidocaldarius. We purified the Saci_0814 protein and characterized its helicase activity. In addition, we isolated the deletion mutant for the corresponding gene in the $S$. acidocaldarius genome and demonstrated a decrease in HR frequency. Our findings suggest that Saci_0814 acts as a functional branch migration helicase in this archaeon.

\section{Results}

\subsection{Prediction of Saci_0814 as a Putative Helicase}

Cubeddu and White reported candidate proteins interacting with the ssDNA-SSB complex in their study on SSB from S. solfataricus [39]. An SF2 helicase (SSO0394) with unknown functions was included in the candidate proteins. A homolog protein of SSO0394 was found in the S. acidocaldarius genome. Saci_0814 shared 54\% sequence identity with SSO0394 over the entire amino acid sequence. Comprehensive phylogenetic analysis of the SF2 helicases in living organisms showed that the archaeal Lhrs were divided into four phylogenetically distinct groups, namely, aLhr1, aLhr2, aLhr3, and aLhr-like [25]. The cysteine-rich motif at the C-terminus region is a specific feature of aLhr1, and neither bacterial Lhr nor the other archaeal Lhrs possess it [25]. This region has a consensus sequence of CPKCGSRM(LIV)(AT)(AV)(LV)(KN)PW [24]. Saci_0814 has a similar sequence, CTKCGSIFLTVTDED (the identical sequence is underlined); therefore, we designated Saci_0814 as SacaLhr1 (alhr1 as the gene name) here, and investigated its function in vivo and in vitro. 


\subsection{Construction of the alhr1-Deleted Strain of S. acidocaldarius}

To investigate the role of SacaLhr1 in vivo, we constructed a deletion mutant strain of S. acidocaldarius for the gene encoding SacaLhr1 from the parental DP-1 strain (Supplemental Figure S1A). The isolated strains were subjected to PCR using primers designed for both the inner and outer regions of alhr1, to confirm the deletion of the target gene from the genome. The shortened PCR product was obtained using the outer primers from the genomic DNA of the isolated strain (Supplemental Figure S1B: lanes DP-1 and 17), but no amplification product was detected by PCR with internal primers (Supplemental Figure S1C). These results indicated complete deletion of the alhr1 gene in the genomic DNA of the strain. This strain was designated as DP-17 (Table 1).

Table 1. Strains or DNAs used in genetic study.

\begin{tabular}{|c|c|c|}
\hline Strains or DNAs & Relevant Characteristic (s) & Source or Reference \\
\hline \multicolumn{3}{|l|}{ Strains } \\
\hline \multicolumn{3}{|l|}{ S. acidocaldarius } \\
\hline DP-1 & SK-1 [40] with $\Delta p h r(\Delta p y r E \Delta s u a I \Delta p h r)$ & {$[41]$} \\
\hline DP-17 & $\begin{array}{l}\text { DP-1 with } \Delta a l h r 1 \\
(\Delta p y r E \Delta \text { suaI } \Delta p h r \Delta a l h r 1)\end{array}$ & This study \\
\hline \multicolumn{3}{|l|}{ Plasmids } \\
\hline placSpyrE & $\begin{array}{l}\text { Plasmid DNA carrying } 0.8 \mathrm{~kb} \text { of } 5^{\prime} \text { and } 3^{\prime} \text { flanking regions of suaI locus at both } \\
\text { ends of pyrE-lacS dual marker }\end{array}$ & {$[41]$} \\
\hline pSAV2 & $\begin{array}{l}\text { Sulfolobus-E. coli shuttle vector, based on pBluescript II KS (-) and pRN1, with the } \\
\text { SsopyrEF maker }\end{array}$ & {$[40]$} \\
\hline \multicolumn{3}{|c|}{ T / } \\
\hline MONSTER-alhr1 & $\begin{array}{l}\text { Linear DNA carrying a } 39 \mathrm{bp} \text { region of alhr } 1 \text { as the Tg-arm, and the } 39 \mathrm{bp} 3^{\prime} \text { and } \\
30 \mathrm{bp} 5^{\prime} \text { flanking regions of alhr1 at both ends of pyrE-lacS dual marker }\end{array}$ & This study \\
\hline pyrElacS800 & $\begin{array}{l}\text { Linear DNA carrying } 0.8 \mathrm{~kb} \text { of } 5^{\prime} \text { and } 3^{\prime} \text { flanking regions of suaI locus at both ends } \\
\text { of pyrE-lacS dual marker }\end{array}$ & {$[41]$} \\
\hline
\end{tabular}

\subsection{Estimation of HR Frequencies}

To investigate the in vivo role of SacaLhr1 on HR in S. acidocaldarius, the HR frequency of DP-17 was compared with that of the parent strain, DP-1. In this analysis, the selectable marker (lacS-pyrE) could only be maintained if it was integrated into the host genome by HR via a double crossover between the linear marker cassette (pyrElacS800) and the chromosome at the $5^{\prime}$ and $3^{\prime}$ homologous regions of the target locus (see Materials and Methods section). The autonomously replicating shuttle vector pSAV2 containing pyrE was used as a control to determine the transformation efficiency of this experiment.

The difference in transformation efficiency of DP-1 and DP-17 was not statistically significant ( $p>0.001$, two-tailed Student's $t$-test) (Supplemental Figure S2A), suggesting that the DNA uptake capacities of both strains were similar. For this reason, we considered that HR efficiency could be compared by counting transformant cells on the selection plates of the two strains. The number of transformants from DP-17 was 5-fold lower than that from DP-1 ( $p=0.00083$ ) (Supplemental Figure S2B). These results indicate that SacaLhr1 is involved in the HR process in S. acidocaldarius in vivo.

\subsection{Purification of the Recombinant Protein Encoded by alhr1}

To determine the function of SacaLhr1 in the HR process, biochemical characterization of this protein was necessary. Therefore, we cloned the alhr1 gene into the expression plasmid and produced the SacaLhr1 protein in E. coli cells. Production of the recombinant SacaLhr1 protein was designed as an N-terminal His-tagged form, and it was successfully overexpressed in a soluble fraction from E. coli C41 (DE3) cells. The expression of SacaLhr1 in the C41 (DE3) cells was crucial for increasing protein solubility because the protein was hardly produced in a soluble fraction when E. coli BL21 (DE3) was used as a host cell. The gel filtration profile in the last step of purification is shown in Figure 1A. The 
molecular weight of the protein estimated from the elution profile was $9.7 \times 10^{4}$, which was approximately 106,353, as calculated from the deduced amino acid sequence of His-tagged SacaLhr1, suggesting that SacaLhr1 exists as a monomer in solution. The recombinant protein was purified to near homogeneity, as determined by SDS-PAGE analysis (Figure 1B). The relative molecular mass of the protein estimated from its migration position in the SDS-PAGE gel corresponded to 106,353. From a $1 \mathrm{~L}$ culture (7.2 g wet cells), $1.5 \mathrm{mg}$ of homogeneous protein was obtained.

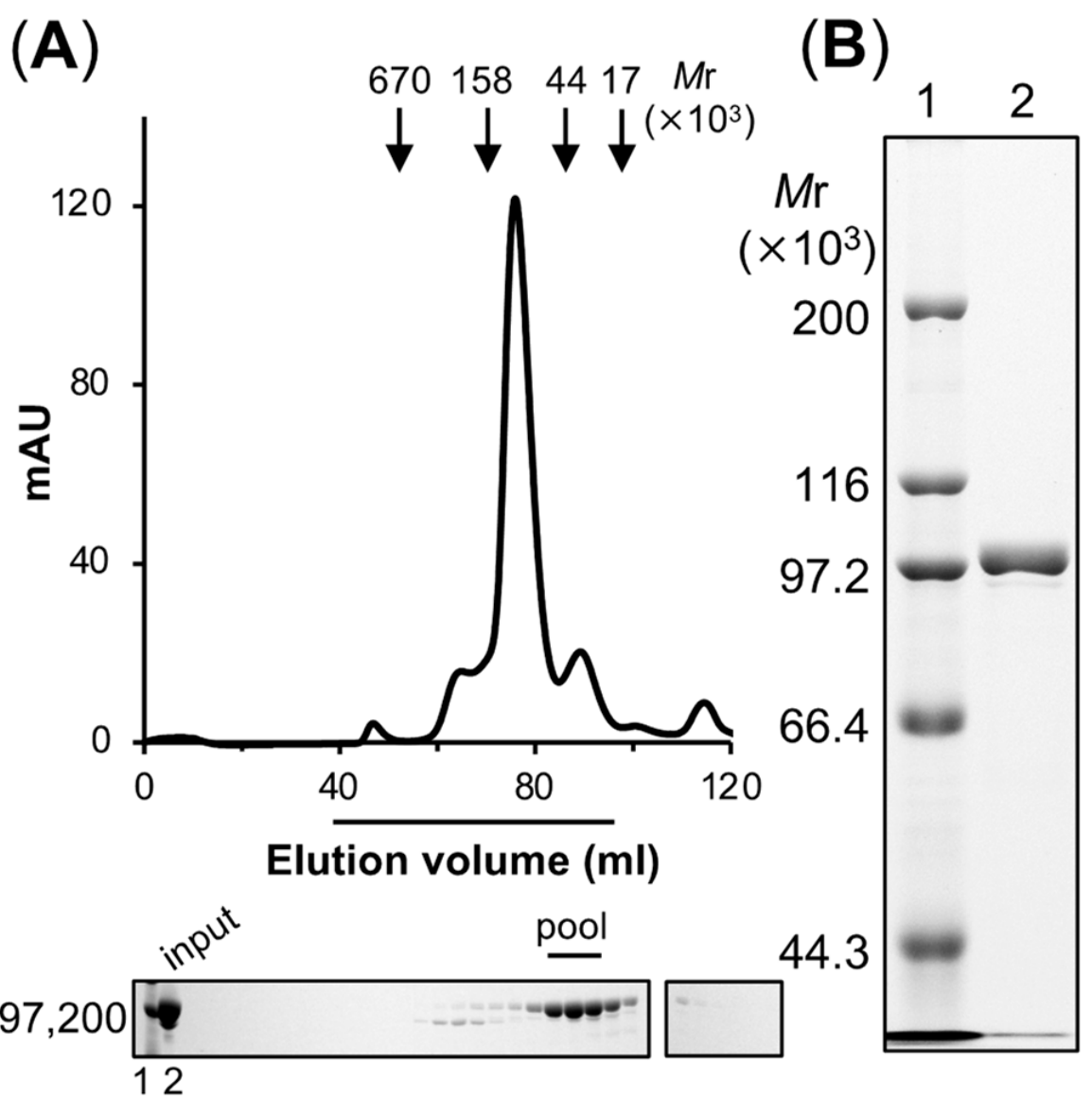

Figure 1. Preparation of recombinant SacaLhr1 protein. (A) Gel filtration chromatography of SacaLhr1 following His-tag purification. Arrowheads indicate the elution profile of standard marker proteins, and the numbers indicate relative molecular masses. Fractions indicated by underbar were subjected to SDS-7.5\% PAGE followed by staining with Coomassie Brilliant Blue (CBB) and are shown under the chromatogram. Lanes 1 and 2 are the protein marker $(M r, 97,200)$ and input, respectively. Three fractions were pooled and used for subsequent experiments. (B) Protein markers (lane 1) and the purified SacaLhr1 (1 $\mu \mathrm{g}$ ) (lane 2) were separated using SDS-7.5\% PAGE and stained with CBB. Sizes of the markers are shown to the left of the panel.

\section{5. ss/dsDNA-Dependent ATPase Activity of SacaLhr1}

The purified SacaLhr1 protein was subjected to ATPase assay in the presence and absence of ssDNA or dsDNA. As shown in Figure 2, the SacaLhr1 protein itself weakly hydrolyzed ATP, and this ATPase activity was clearly stimulated in the presence of increasing concentrations of ss/dsDNA. Notably, SacaLhr1 is an ss/dsDNA-dependent ATPase, and ssDNA is preferable to dsDNA for its activity. The ss/dsDNA-dependent ATPase activity has also been demonstrated for P. furiosus $\mathrm{Hjm}$, in which ATPase activity is stimulated in the presence of ss/dsDNA with the same efficiency [13]. However, the preference for ssDNA is more obvious for the ATPase activity of $M$. thermautotrophicus Hel308, which is stimulated considerably by ssDNA, but not dsDNA [12]. Different properties have also been reported for S. solfataricus aLhr2 [21] and S. islandicus PINA [16], in which ATPases 
were not stimulated in the presence of ss/dsDNA. Here, the ATPase activity of SacaLhr1 was clearly stimulated by both ssDNA and dsDNA.

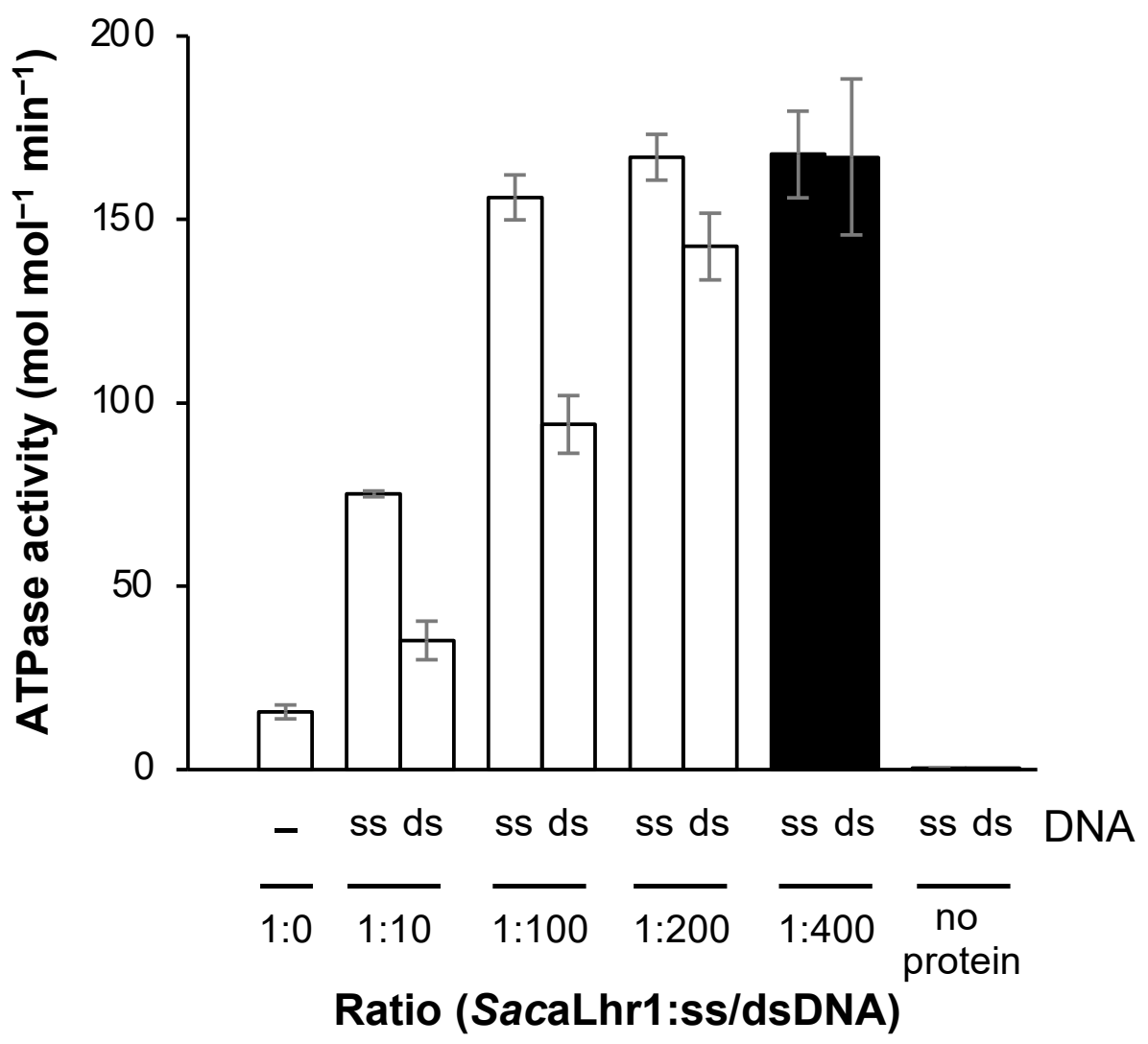

Figure 2. ss/dsDNA-dependent ATPase activity of SacaLhr1. ATP activity refers to the amount of released $\mathrm{Pi}(\mathrm{mol})$ by a constant amount of the SacaLhr1 (1 mol as a monomer) for a 1-min incubation under each reaction condition in the absence $(-)$ or presence of ssDNA or dsDNA at a ratio of SacaLhr1:ss/dsDNA = 1:0-400 and 0:400. One at the ratio means 2.25 pmol. Reactions carried out without SacaLhr1, in the presence of $900 \mathrm{pmol}$ ss/dsDNA (indicated as no protein) were considered as the negative control. Data are presented as mean \pm standard deviation (SD), calculated from values of three independent experiments.

\subsection{SacaLhr1 Is a $3^{\prime}$-to-5' DNA Helicase}

The DNA-strand unwinding activity of the SacaLhr1 protein was investigated using normal duplex DNA with a single-stranded region at either the $5^{\prime}$ - or $3^{\prime}$-end. The duplex DNA with $34 \mathrm{bp}$ and 20 or 24 nt of the single-stranded region for $5^{\prime}$ - and $3^{\prime}$-end, respectively, were used as substrates. As shown in Figure 3, SacaLhr1 clearly showed unwinding activity for the DNA with $3^{\prime}$-protruding (Figure 3A), but not for the DNA with $5^{\prime}$-protruding ssDNA (Figure 3B). This result indicates that SacaLhr1 unwinds the DNA strand in the $3^{\prime}$-to-5' direction. It has been suggested that the $3^{\prime}$-to- $5^{\prime}$ polarity of the helicase of SacaLhr1 is a common function rather than a distinctive feature because it has also been reported for aLhr2 from S. solfataricus [21], S. acidocaldarius [22], and M. thermautotrophicus [23]; Hjm from P. furiosus [13]; Hel308 from M. thermautotrophicus [12]. 

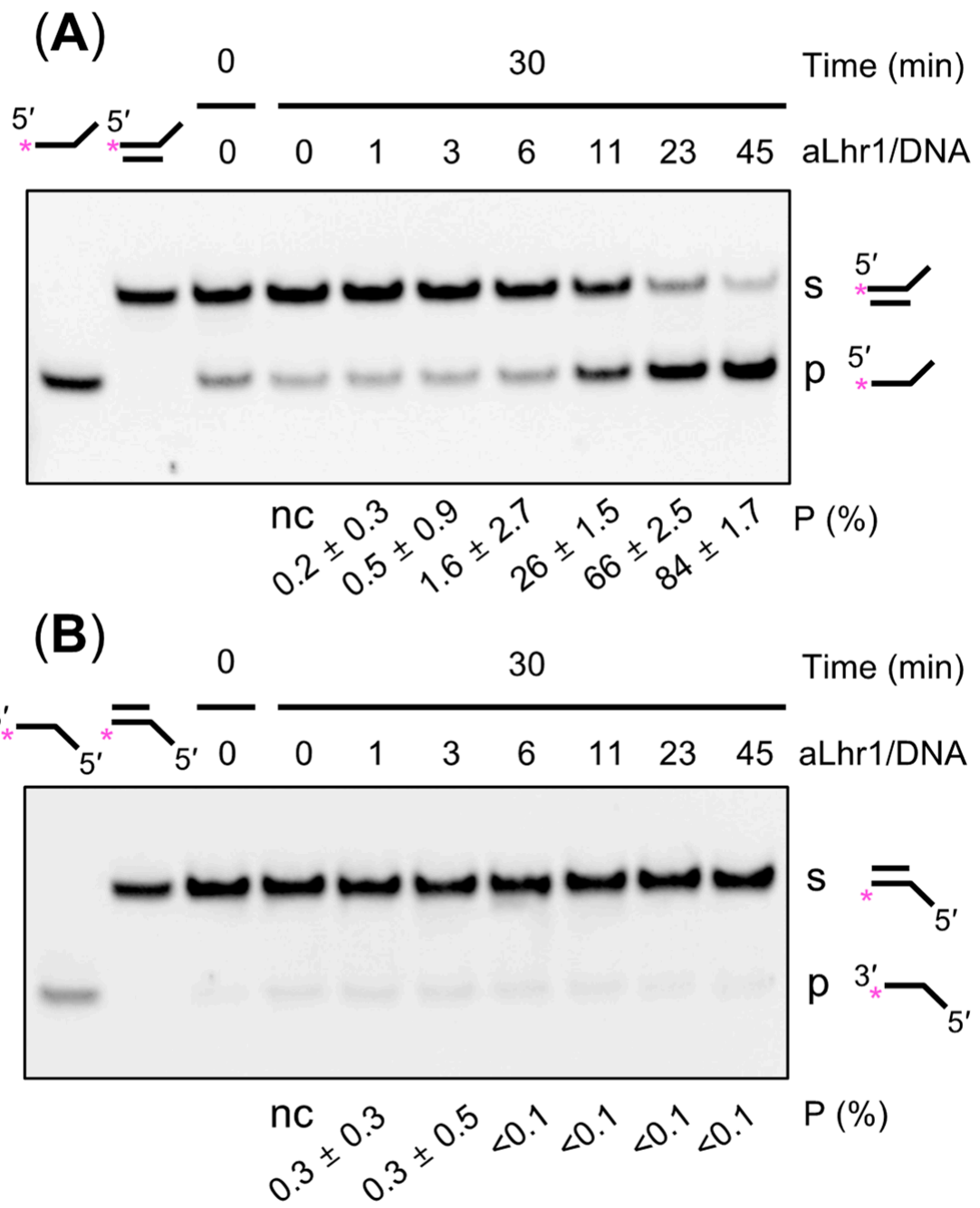

Figure 3. SacaLhr1 is a $3^{\prime}$-to- $5^{\prime}$ DNA helicase. We incubated $10 \mathrm{nM}$ of $3^{\prime}$-protruding DNA (A) and a $5^{\prime}$-protruding DNA (B) with the indicated ratio of SacaLhr1 and DNA (aLhr1/DNA) at $70{ }^{\circ} \mathrm{C}$ for 30 min. Asterisks in $(\mathbf{A}, \mathbf{B})$ indicate $5^{\prime}$ - and $3^{\prime}-\mathrm{Cy} 5$ labels, respectively. The band assignments are indicated on the right side of the panels ( $\mathrm{s}$, substrates; $\mathrm{p}$, products). Reactions were quantified by measuring the band intensities and expressed as P\% (product per total DNA) and are indicated under each lane. Value from the negative control reaction without protein (nc, negative control) was subtracted from each value. Data are presented as mean $\pm \mathrm{SD}$, calculated from values of three independent experiments.

\subsection{ATP-and $\mathrm{Mg}^{2+}$-Dependent Helicase Activity of SacaLhr1}

Helicase activity often requires energy from ATP hydrolysis and divalent cations as cofactors. To examine the effect of ATP and $\mathrm{Mg}^{2+}$ on the helicase activity of SacaLhr1, a helicase assay using a synthetic oligonucleotide substrate and trap DNA designed by Ogino et al. [42] was used. A splayed DNA (comprising a 34-bp duplex with a 20-nt long $5^{\prime}$-single-stranded tail and 36-nt long $3^{\prime}$-single-stranded tail) was prepared using two oligonucleotides, one of which was labeled with Cy5 at the $5^{\prime}$-terminus. The trap DNA can anneal with the labeled oligonucleotide after unwinding of the splayed DNA for protection from reannealing to the splayed DNA (Table 2). 
Table 2. Substrates and trap DNAs used in this study.

\begin{tabular}{|c|c|}
\hline Name & Sequence $\left(5^{\prime}-3^{\prime}\right)$ or Combination for Annealing \\
\hline \multicolumn{2}{|c|}{ Labeled oligonucleotides $^{\text {a }}$} \\
\hline & Cy5- \\
\hline (у)-HJ4-59 & GACCTAGGAACCACCAGAAACACGCCACAGCCAGGAAGCCGATTGCGAGGCCGTCCTAC \\
\hline Сy5-HJ3-54 & Су5-TCACTCCGCATCTGCCGATTCTGGCTGTGGCGTGTTTCTGGTGGTTCCTAGGTC \\
\hline HJ3-54mer-Cy5 & TCACTCCGCATCTGCCGATTCTGGCTGTGGCGTGTTTCTGGTGGTTCCTAGGTC-Cy5 \\
\hline DyLight 5-HJ2S & DyLight 5-CGTTGACATCTCGCGTGCTCGGTCAATCGGCAGATGCGGAGTGAAGTTCC \\
\hline \multicolumn{2}{|r|}{ O } \\
\hline HJ4-34 & GACCTAGGAACCACCAGAAACACGCCACAGCCAG \\
\hline HJ4-34-R & CTGGCTGTGGCGTGTTTCTGGTGGTTCCTAGGTC \\
\hline HJ4 & $\begin{array}{l}\text { GACCTAGGAACCACCAGAAACACGCCACAGCCAGGAAGCCGATTGCGAGGCCGTCCT } \\
\text { ACCATCCTGCAGG }\end{array}$ \\
\hline HJ1S & GGTAGGACGGCCTCGCAATCGGCTTCGACCGAGCACGCGAGATGTCAACG \\
\hline $\mathrm{HJ} 3 \mathrm{~S}$ & GGAACTTCACTCCGCATCTGCCGATTCTGGCTGTGGCGTGTTTCTGGTGG \\
\hline $\mathrm{HJ} 4 \mathrm{~S}$ & CCACCAGAAACACGCCACAGCCAGGAAGCCGATTGCGAGGCCGTCCTACC \\
\hline HJ2S-RC & GGAACTTCACTCCGCATCTGCCGATTGACCGAGCACGCGAGATGTCAACG \\
\hline HJS1-2-trap & GGAACTTCACTCCGCATCTGCCGATTGAAGCCGATTGCGAGGCCGTCCTACC \\
\hline HJS2-3-trap & CCACCAGAAACACGCCACAGCCAGGACCGAGCACGCGAGATGTCAACG \\
\hline \multicolumn{2}{|l|}{ DNA substrates $b$} \\
\hline $3^{\prime}$-overhang & Cy5-HJ4-59/HJ4-34-R \\
\hline $5^{\prime}$-overhang & HJ3-54mer-Cy5/HJ4-34 \\
\hline Splayed DNA1 & Су5-HJ3-54/HJ4 \\
\hline ssDNA & DyLight $5-\mathrm{HJ} 2 \mathrm{~S}$ \\
\hline dsDNA & DyLight 5-HJ2S/HJ2S-RC \\
\hline Splayed DNA2 & DyLight 5-HJ2S/HJ3S \\
\hline Y-junction1 & HJ1S/DyLight 5-HJ2S/HJS1-2-trap \\
\hline Y-junction2 & DyLight 5-HJ2S/HJ3S/HJS2-3-trap \\
\hline Three-strand DNA1 & DyLight 5-HJ2S/HJ3S/HJ4S \\
\hline Three-strand DNA2 & HJ1S/DyLight 5-HJ2S/HJ4S \\
\hline Three-strand DNA3 & HJ1S/DyLight 5-HJ2S/HJ3S \\
\hline HJS & HJ1S/DyLight 5-HJ2S/HJ3S/HJ4S \\
\hline
\end{tabular}

${ }^{a}$ Substrate labeled at their $5^{\prime}$ or $3^{\prime}$ ends are denoted with Cy 5 or DyLight $5 .{ }^{b}$ Various combinations of oligonucleotides were used to generate substrates, as indicated.

The effect of ATP and $\mathrm{Mg}^{2+}$ on the helicase activity of SacaLhr1 was studied over a reaction time of $15 \mathrm{~min}$. A time-dependent unwinding reaction was observed in a linear relationship (Figure 4A,B). The unwinding activity was ATP-dependent and the reaction was efficient with an ATP concentration of $0.2-2 \mathrm{mM}$ (Figure 4C). A small amount of the product was detected in the absence of $\mathrm{MgCl}_{2}$ (Figure 4D). However, when EDTA was added, the residual unwinding reaction was partially inhibited (Figure 4D). The helicase activity was accelerated by $\mathrm{Mg}^{2+}$, and the reaction was efficient at a $\mathrm{Mg}^{2+}$ concentration range of $2.5-15 \mathrm{mM}$ (Figure 4D). These results indicate that SacaLhr1 is an ATP- and $\mathrm{Mg}^{2+}$-dependent helicase. This condition ( $1 \mathrm{mM}$ ATP and $5 \mathrm{mM} \mathrm{MgCl} 2$ ) was used for subsequent assays.

\subsection{Unwinding Activity SacaLhr1 on Branched DNA}

To investigate whether SacaLhr1 has branch migration activity, dissociation activity against a synthetic HJ (HJS: 50-nt long oligonucleotides forming a four-way junction with no homologous region) (Table 2) by SacaLhr1 was characterized (Figure 5). If the protein had a branch migration activity for the HJ DNA, a half junction (Y-structure or splayed DNA) could be formed from HJS. However, SacaLhr1 unwound HJS, producing ssDNA as the main product (Figure 5). This unwinding property of SacaLhr1 is similar to that of aLhr2 from S. acidocaldarius [22] but not those of other candidates for branch migration helicase, for which ssDNA and a half junction were detected as products at similar levels [11,16,23]. SacaLhr1 also unwound a synthetic three-way junction (Y-junction2), but not normal duplex DNA, producing ssDNA (Figure 5). At this point, it is not clear whether SacaLhr1 has 
branch migration activity for HJ-structured DNA. However, this enzyme has a strand unwinding activity, specifically for Y-junction2 and HJS, which contain a branch point that produces ssDNA.

(A)

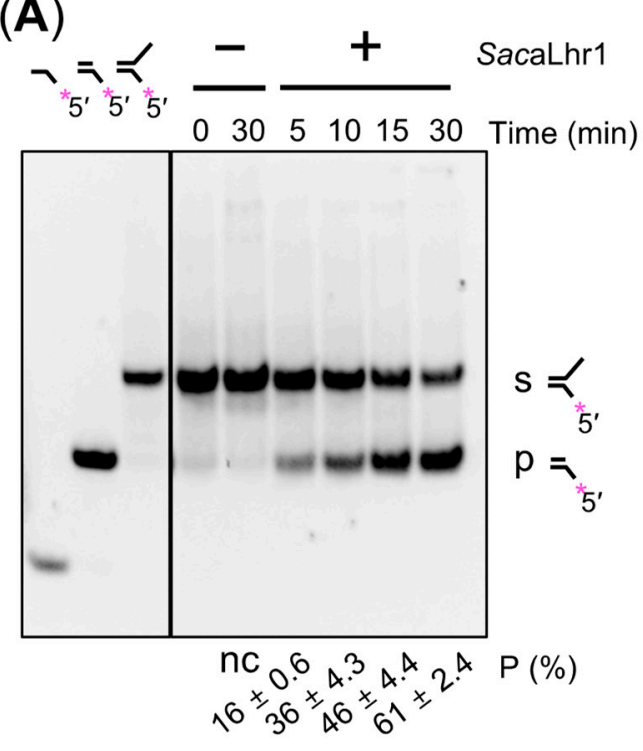

(B)

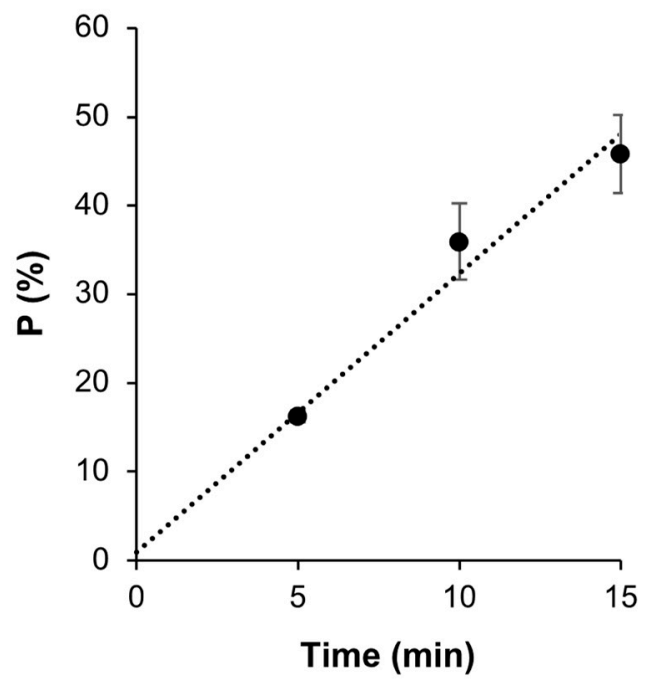

(D) SacaLhr1 ATP $(\mathrm{mM})$

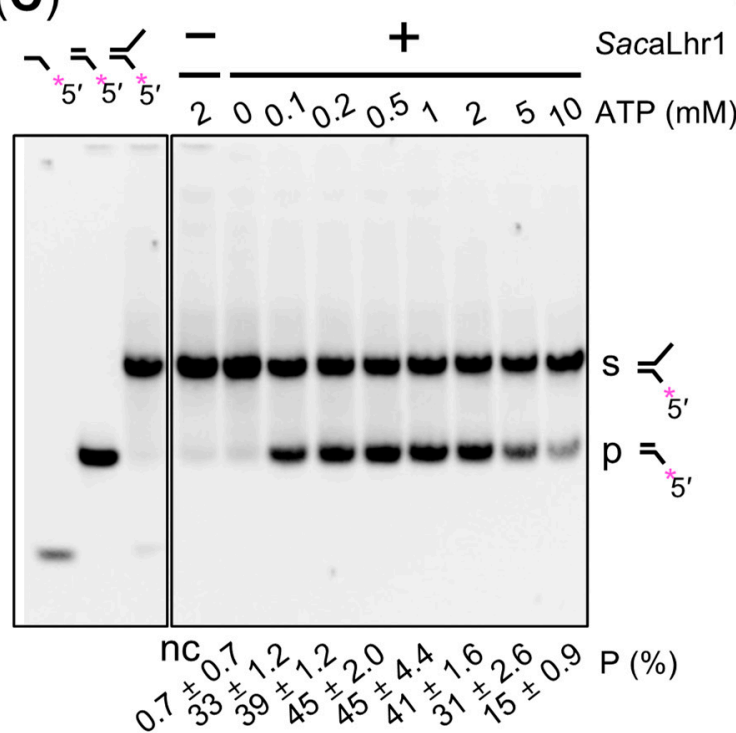

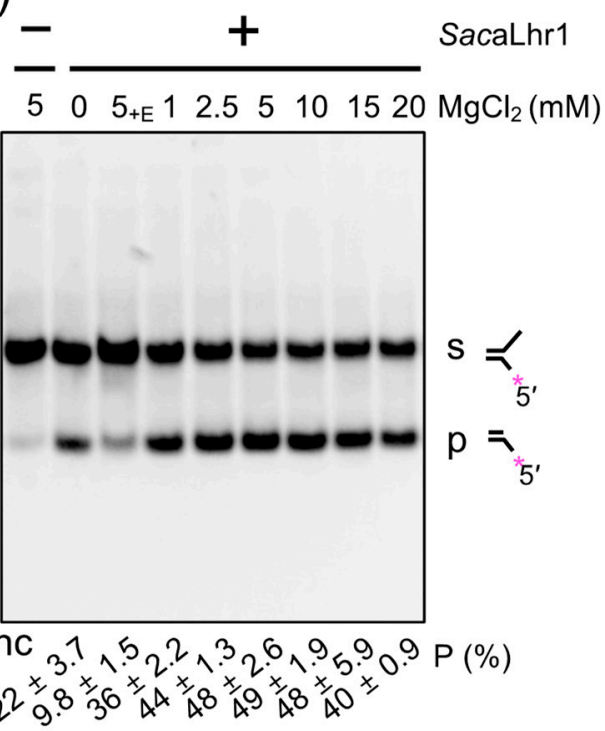

Figure 4. ATP- and $\mathrm{Mg}^{2+}$-dependent helicase activity of SacaLhr1. (A) Time-course analysis of helicase activity. Splayed DNA1 (10 nM) was incubated with (+) or without (-) SacaLhr1 (225 nM) at $60{ }^{\circ} \mathrm{C}$ for 0-30 min. (B) Reactions in (A) were quantified and plotted. SD was calculated from three independent experiments. ATP $(\mathbf{C})$ and $\mathrm{Mg}^{2+}$ (D) dependences of the helicase activity were examined. Reactions were performed at $60{ }^{\circ} \mathrm{C}$ for $15 \mathrm{~min}$ in the presence of $5 \mathrm{mM} \mathrm{MgCl}_{2}$ with indicated concentrations of ATP in (C) and $2 \mathrm{mM}$ ATP with indicated concentrations of $\mathrm{MgCl}_{2}$ in (D). + E indicates reaction containing 0.1 M EDTA. Asterisks represent $5^{\prime}$-Cy5 labels. The band assignments are indicated on the right side of the panels, s, substrates; $\mathrm{p}$, products. Reactions were quantified by measuring the band intensities and expressed as P\% (product per total DNA) and are indicated under each lane. Value from the negative control reaction without protein (nc, negative control) was subtracted from each value. Data are presented as mean $\pm \mathrm{SD}$, calculated from values of three independent experiments. 


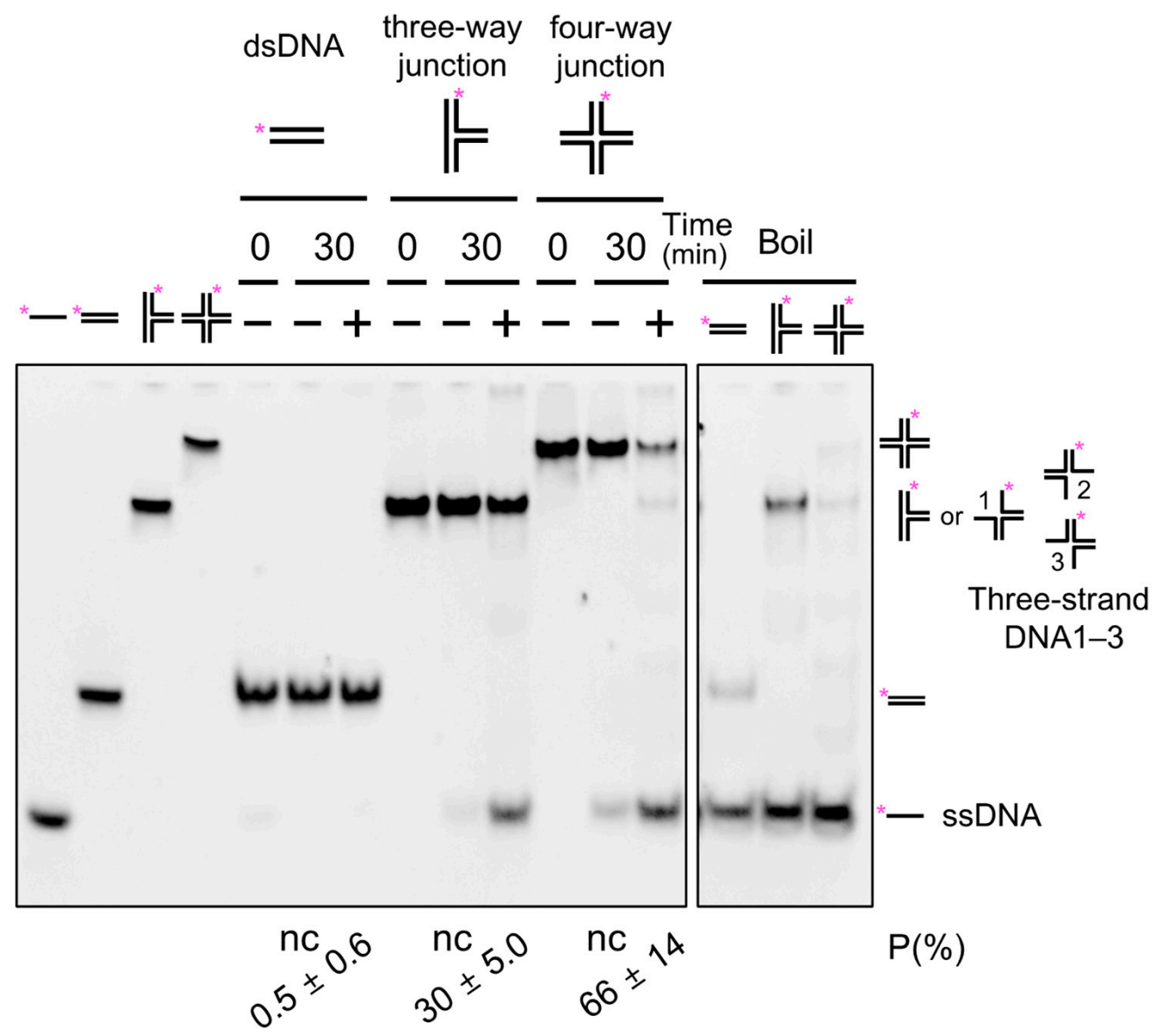

Figure 5. Helicase activity of SacaLhr1 for branched DNA molecules. dsDNA, three-way junction (Y-junction2), and four-way junction (HJS) $(10 \mathrm{nM})$ were incubated with (+) or without (-) SacaLhr1 $(123 \mathrm{nM})$ at $70^{\circ} \mathrm{C}$ for $30 \mathrm{~min}$. Reactions were performed without trap DNA. Asterisks represent $5^{\prime}$-DyLight 5 labels. "Boil" indicates boiling of the substrate at $98^{\circ} \mathrm{C}$ for $3 \mathrm{~min}$ followed by cooling on ice water. Detected bands were assigned using the controls of each shaped DNA on the right side of the panel. Reactions were quantified by measuring the band intensities and expressed as P\% (product per total DNA) and are indicated under each lane. Value from each negative control reaction without protein (nc, negative control) was subtracted from each value. Data are presented as mean $\pm S D$, calculated from values of three independent experiments.

\subsection{Binding Properties of SacaLhr1 to DNA with or without a Branch Point}

To determine whether SacaLhr1 specifically recognizes the branch point of DNA, the binding properties of SacaLhr1 to DNA substrates with or without the branch point (ssDNA, dsDNA, splayed DNA2, Y-junction2, and HJS) were examined. The binding preference of SacaLhr1 was not significantly different among the DNA substrates (Figure 6). Multiple shifted bands were observed for all the DNA substrates used for the EMSA. It was not easy to assign each shifted band at this stage, but it was clear that SacaLhr1 preferably bound the DNA molecules with a single-stranded region (ssDNA and splayed DNA2) (Figure 6A-C). SacaLhr1 bound to HJS, Y-junction2, and dsDNA with about the same efficiency (Figure 6B,D,E). The binding preference of SacaLhr1 to ssDNA, compared with dsDNA, was consistent with the result of its DNA-dependent ATPase activity, wherein ATPase activity was more stimulated by ssDNA than dsDNA (Figure 2). No specific binding to a branch point by SacaLhr1 was demonstrated. The binding properties of SacaLhr1 are similar to those of Hjm from P. furiosus [13]. However, no clear difference in the binding properties of SacaLhr1 to synthetic HJ and dsDNA were observed. This lack of binding preference for SacaLhr1 is distinct from that of aLhr2 from S. acidocaldarius, Hjm 
from S. tokodaii, Hel308 from M. thermautotrophicus, and PINA from S. islandicus. These helicases preferably bind to a synthetic HJ over dsDNA [12,15,16,22].

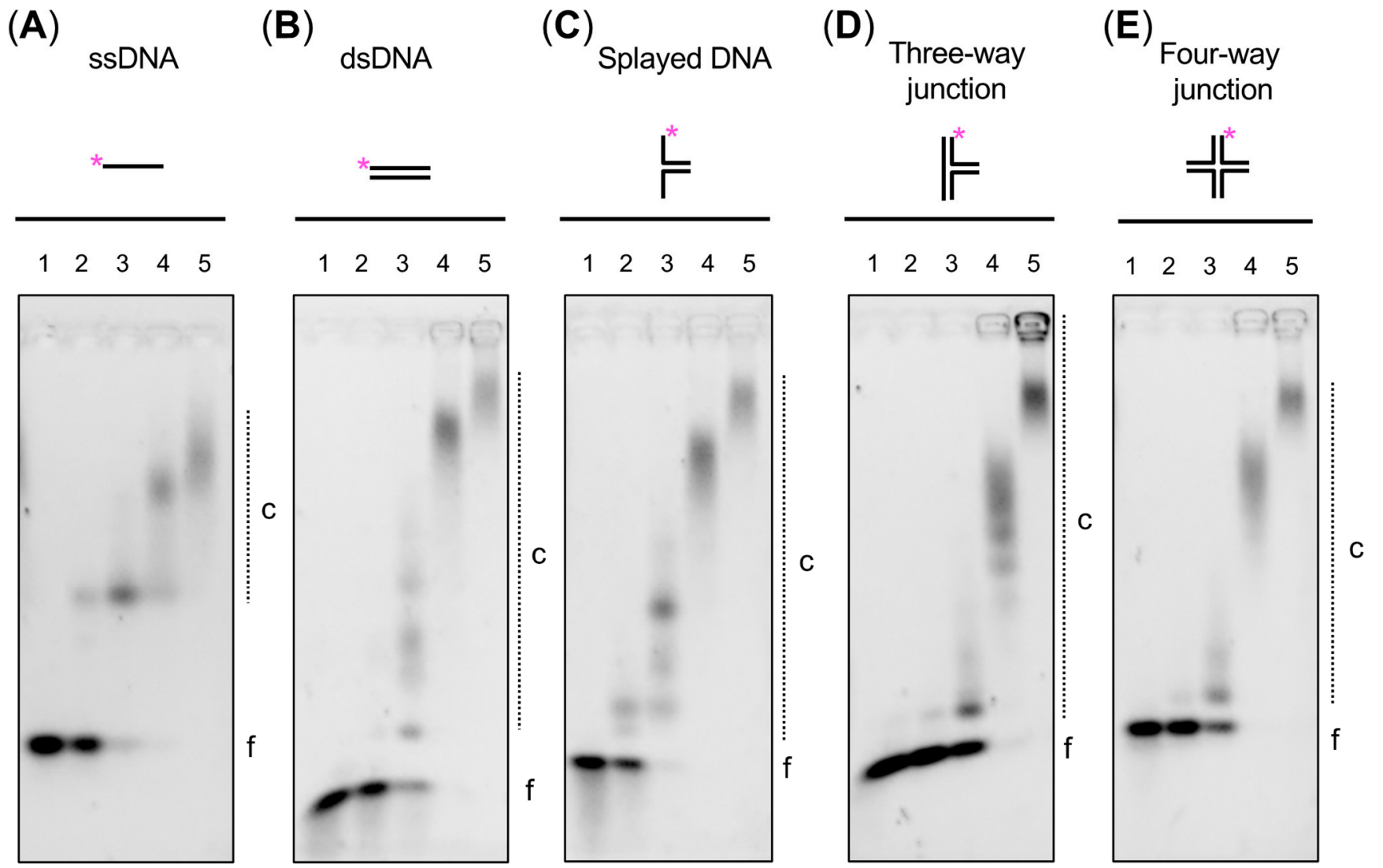

Figure 6. DNA-binding properties of SacaLhr1. DNA molecules $(10 \mathrm{nM})$ with various structures (ssDNA (A), dsDNA (B), splayed DNA2 (C), Y-junction2 (D), and HJS (E)) were incubated with increasing concentrations of SacaLhr1 (lane 1, no protein; 2, $60 \mathrm{nM} ; 3,110 \mathrm{nM} ; 4,230 \mathrm{nM} ; 5,450 \mathrm{nM}$ ) at $25^{\circ} \mathrm{C}$ for $10 \mathrm{~min}$. Asterisks in (A-E) represent $5^{\prime}$-DyLight 5 labels. Products were separated by $1 \%$ or $2 \%$ agarose gel in $0.1 \times$ TBE. Band assignments are indicated on the side of the panels (c, protein-DNA complexes; f, free DNA). Experiments were repeated thrice, and representative gel images are shown.

\subsection{Branch Migration Activity of SacaLhr1 against a Synthetic HJ}

SacaLhr1 unwound the synthetic HJ, HJS, producing ssDNA (Figure 5). Regarding the unwinding reaction, two processes were considered as possible mechanisms: (i) SacaLhr1 binding a single-stranded region generated by thermal denaturation at high temperature followed by direct unwinding of HJS in the $3^{\prime}-$ to $-5^{\prime}$ direction from the produced ssDNA. (ii) The inability of SacaLhr1 to unwind the duplex DNA without a $3^{\prime}$-single-stranded tail, as shown above, implied that it was unlikely that SacaLhr1 directly unwound HJS to produce ssDNA. As shown in Figure 7A, SacaLhr1 possibly first dissociates HJS to the half junctions, using its branch migration activity, and then unwinds the half junctions to the ssDNA in the $3^{\prime}$-to-5' direction. Thus, we assessed whether SacaLhr1 dissociated HJS to half junctions using its branch migration activity. 
(A)

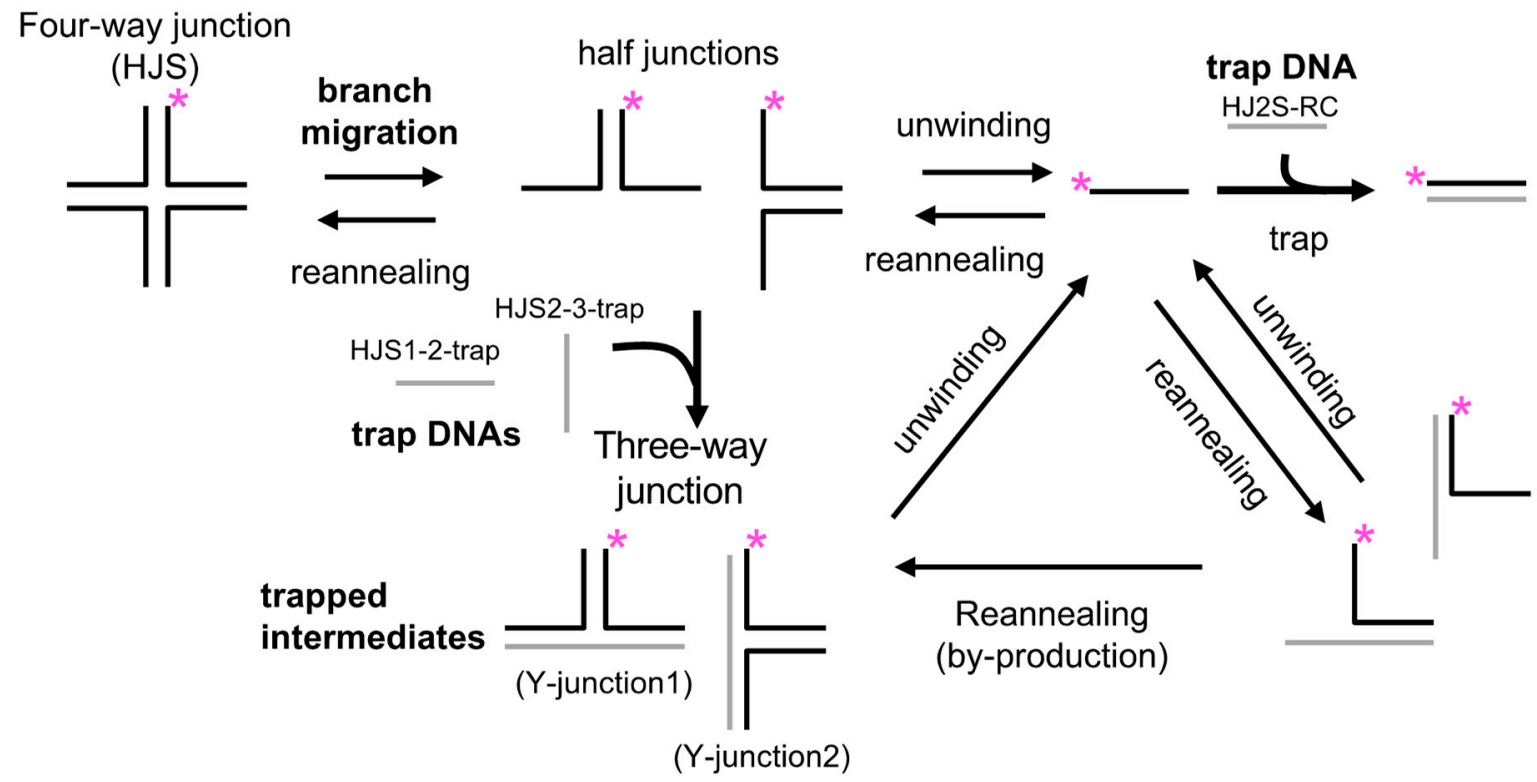

(B)

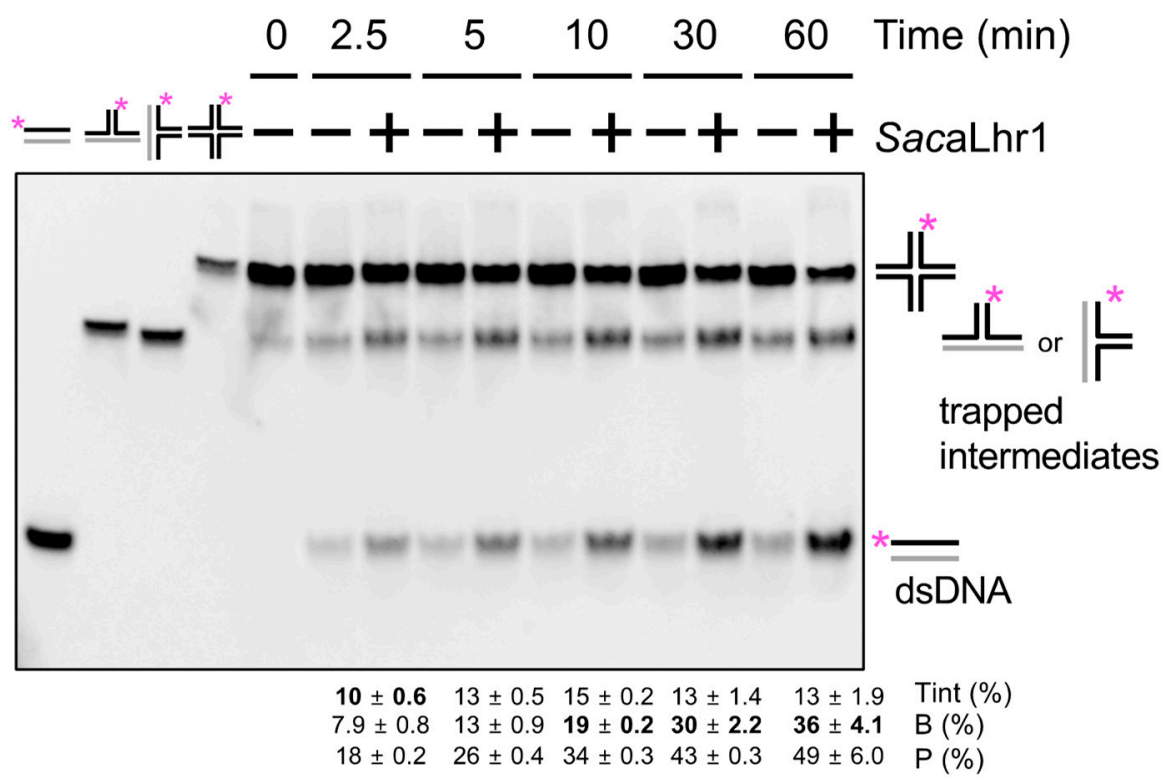

Figure 7. Branch migration activity of SacaLhr1 for synthetic HJ. (A) Schematic drawing of the possible unwinding and reannealing processes of substrate DNA. Gray lines and asterisks indicate the trap DNA molecules and 5'-DyLight 5 labels, respectively. (B) Synthetic $\mathrm{HJ}(10 \mathrm{nM})$ were incubated with (+) or without (-) SacaLhr1 $(225 \mathrm{nM})$ at $70{ }^{\circ} \mathrm{C}$ for $0-60 \mathrm{~min}$. Bands were assigned and indicated on the right side of the panel. Amounts of trapped intermediates (Tint\%) (trapped intermediates per total DNA), dsDNA (B\%) (dsDNA per total DNA), and product (P\%) (trapped intermediates and dsDNA per total DNA) were quantified using band intensities obtained via scanning the gel image and indicated under the panel. For each band, intensity from the control reaction without protein was subtracted. Experiments were repeated thrice, and representative gel images are shown.

To evaluate the formation of half junctions, an assay to trap the half junctions was developed (Figure 7A). Under these conditions, three trap DNA molecules were designed. Two of the trap DNA molecules (HJS1-2-trap and HJS2-3-trap) could hybridize to each of the two half-junctions produced from HJS (Table 2), thus producing the trapped intermediates Y-junction1 and Y-junction2 (Figure 7A). The third trap DNA (HJ2S-RC) comprised a 
complementary strand of the $5^{\prime}$-DyLight 5 labeled ssDNA (one of the four DNA strands consisting of HJS) to prevent reannealing the labeled ssDNA with the other trap DNA (HJS1-2-trap and HJS2-3-trap) and the unwound DNA (HJ1S and HJ3S) from half junctions (Figure 7A).

The unwinding process of HJS, catalyzed by SacaLhr1, was examined in a timedependent manner in the presence of the three trap DNA molecules. As shown in Figure 7B, the number of trapped half junctions (Tint $\%$ ) was higher than that of the trapped ssDNA $(\mathrm{B} \%)$, but $\mathrm{B} \%$ increased with longer reaction times. Quantification of each band showed that Tint $\%$ was higher than that of $\mathrm{B} \%$ at $2.5 \mathrm{~min}$. However, $\mathrm{B} \%$ increased with increasing reaction times, and the difference values was reversed after $10 \mathrm{~min}$. Tint $\%$ without protein was constant throughout the reaction. These results suggest that SacaLhr1 promotes the branch migration reaction for synthetic HJ.

\section{Discussion}

Homologous recombination plays a very important role in maintaining the genome stability of HA. However, its molecular mechanism in Archaea is not fully elucidated. From the many studies on each step of HR in Archaea, Hjm/Hel308 [11,12,15], PINA [16], and aLhr2 [23] have been characterized in vitro as candidate branch migration helicases. However, it remains unclear whether these candidates are essential for branch migration to process the recombination intermediate in Archaea in vivo. In this study, we noted that the alhr1-deleted strain of $S$. acidocaldarius exhibited a defect in HR frequency (5-fold decrease) when compared with the parental strain (Supplemental Figure S2). A similar decrease in HR frequency has been demonstrated by the deletion of the genes encoding recombinase mediator proteins ( $\operatorname{Rad} 22$ and Rhp57) in Schizosaccharomyces pombe (2- and 5 -fold decrease) $[43,44]$. However, the decrease in HR frequency in the alhr1-deleted strain was lower than that in the recombinase-deleted eukaryotic and archaeal strains (15- or 31-fold decrease in S. pombe and >500-600-fold decrease in Haloferax volcanii) [43-45], but plasmid integration by single-crossover recombination was utilized to estimate HR frequency in previous studies. In our genetic assay, we considered that the selectable marker lacS-pyrE was inserted in the genomic locus by HR via double-crossover consisting of end resection of the linear marker cassette, strand exchange, formation of double HJs, branch migration, and HJ resolution. Thus, the decrease in HR frequency by the deletion of the alhr1 gene (Supplemental Figure S2) suggests that SacaLhr1 is directly involved in the HR process. To investigate whether SacaLhr1 has branch migration activity in vitro, we purified SacaLhr1 and characterized it as a monomer in solution and a ss/dsDNA-dependent ATPase (Figures 1 and 2). SacaLhr1 unwound the DNA duplex with $3^{\prime}$-overhang in the $3^{\prime}$-to- $5^{\prime}$ direction, and dissociated the synthetic $\mathrm{HJ}$ in vitro (Figures 3 and 7). Because SacaLhr1 has branch migration activity (Figure 7), we suggest that SacaLhr1 promotes branch migration of double HJs formed at both homologous ends of the linear marker cassette and extends heteroduplex regions to increase the frequency of crossover recombination, as noted in our genetic assay (Supplemental Figure S2).

As other candidate branch migration helicases, namely, Hjm from P. furiosus [11], aLhr2 from $M$. thermautotrophicus [23], and PINA from S. islandicus [16], also dissociate a synthetic HJ in vitro, we considered SacaLhr1 as another potential branch migration helicase. Although SacaLhr1 does not specifically bind to the synthetic HJ (Figure 6), it may bind to the dsDNA region of the synthetic $\mathrm{HJ}$ and promote branch migration via translocation on dsDNA driven by dsDNA-dependent ATPase activity (Figures 2 and 7). Furthermore, because the dsDNA-dependent ATPase activity of SacaLhr1 is considered to be a distinctive feature in comparison with the candidates for branch migration helicase from other Archaea (Figure 2) [12,16,21], we speculated that Hjm from P. furiosus promoted branch migration via the same mechanism because Hjm also has dsDNA-dependent ATPase activity and binds to a synthetic HJ and dsDNA with mostly the same efficiency [13]. In addition, ssDNA was detected as a product in the helicase reaction by the other candidates for branch migration helicase [11,16,23], suggesting that SacaLhr1 also processed the 
synthetic HJ to ssDNA (Figure 5) by the same process of branch migration followed by a $3^{\prime}$-to- $5^{\prime}$ helicase reaction. Based on our genetic and biochemical analyses, we suggested that SacaLhr1 was involved in the HR process and may act as a branch migration helicase in this archaeon in vivo.

Regarding the decrease in HR frequency in our genetic assay (Supplemental Figure S2), we could not eliminate the possibility that SacaLhr1 stimulates end resection of the linear marker cassette for HR. Similarly, BLM helicase, a member of the RecQ family in humans, stimulates dsDNA resection by EXO1 (5'-to- $3^{\prime}$ dsDNA exonuclease) or DNA2 (helicase/ssDNA endonuclease) in vitro, which are considered to be components of DNA end resection in humans [46,47]. As a functional counterpart in Archaea, DNA helicase HerA from $S$. solfataricus stimulates (restores) dsDNA resection via the partner exo/endonuclease NurA in the presence of ATP in vitro [48]. It is likely that nucleases and helicases play important roles in the end resection step. De Falco et al. [49] demonstrated that aLhr2 from S. solfataricus inhibited nuclease activity of NurA on ss/dsDNA, but not nicking activity on a supercoiled plasmid DNA, in the presence of HerA and in the absence of ATP in vitro. However, its biological significance is not clear because the deletion of the aLhr2-encoding gene in S. acidocaldarius does not affect HR frequency in vivo [22]. It appears that no biochemical studies to date have shown whether aLhr1 physically and functionally interacts with any nucleases; thus, it was difficult to assess the validity of this possibility at this stage. Further research is required to examine whether SacaLhr1 is involved in the end resection.

In terms of the role of SacaLhr1 in the HR process, in addition to the branch migration activity (Figure 7), we found that SacaLhr1 preferentially binds to the ssDNA (Figure 6) and has $3^{\prime}$-to- $5^{\prime}$ helicase activity (Figure 3 ). The cellular significance of its $3^{\prime}$-to- $5^{\prime}$ helicase activity is still unclear; a possible interpretation could be that the helicase activity of SacaLhr1 is involved in the DNA repair process. Previous phylogenetic analysis of SF2 helicases in Archaea suggests that Hjm/Hel308, aLhr1, and aLhr2 seem to have evolved from a common ancestral helicase and share similar functions [24]. In fact, Hjm/Hel308 and aLhr2 have both branch migration activity and $3^{\prime}$-to- $5^{\prime}$ helicase activity $[12,13,22,23]$. In addition, expression of Hjm from P. furiosus, or Hel308 or aLhr2 from M. thermautotrophicus, was observed in E. coli dnaE486 $\Delta$ recQ cells mimicking the RecQ-like growth defect phenotype $[12,13,23,50]$. It has been proposed that RecQ unwinds a stalled replication fork (i.e., fork DNA with a gap on the leading strand) with a $3^{\prime}$-to- $5^{\prime}$ polarity by two-step reactions [50]. Thus, previous genetic results suggest that Hjm/Hel308 and aLhr2 are involved in the repair of stalled replication forks. Based on these observations, the $3^{\prime}$-to- $5^{\prime}$ helicase activity of SacaLhr1 may also be involved in the repair of a stalled replication fork. We did not investigate how SacaLhr1 works for a fork-structured DNA in this study, further biochemical studies are required to elucidate the stalled fork repair process.

Lhr was originally discovered in E. coli, which was followed by continuous biochemical characterization of the homologs from Mycobacterium and Pseudomonas. These studies indicated that bacterial Lhrs are ssDNA-dependent ATPases and 3'-to-5' DNA translocases with unwinding properties both on RNA:DNA and DNA:DNA hybrids [19,20,51]. The capacity to unwind the RNA:DNA hybrid was also reported for aLhr2 from $M$. thermautotrophicus and Thermococcus barophilus [23,25]. The aLhr1 (800-900 aa) is shorter than those from bacteria (1400-1700 aa), which are now classified as bLhr-HTH [25]. The extensional C-terminal domain of bLhr-HTH is required for the formation of a homo-oligomeric quaternary structure [52]. The lack of this C-terminal region in SacaLhr1 is consistent with its monomeric structure in solution (Figure 1A). aLhr1 was found in some DPANN, Asgard, and almost all TACK genomes, in addition to most of the euryarchaeal genomes, except for those of Methanopyraceae, Methanococcales, and Methanobacteriales [25]. Based on the nearly ubiquitous distribution of aLhr1 homologs in Archaea, we suggest that aLhr1 is important for HR in Archaea. Moreover, Methanopyraceae, Methanococcales, and Methanobacteriales may have another counterpart to compensate for the aLhr1 function. Genomic analysis showed that the alhr2, but not alhr1, gene of the Sulfolobales is located near the genes encoding the 
UV-inducible pili [22,25], suggesting that aLhr1 and aLhr2 play distinct roles in Sulfolobales in vivo. Song et al. [53] indicated that the alhr1 (SiRe1605)-deleted strain of S. islandicus exhibited sensitivity to MMS, suggesting that aLhr1 is involved in MMS-induced DNA repair for the alkylation damages. Wolferen et al. [22] argued that aLhr2 of S. acidocaldarius processes $\mathrm{HJ}$ created after UV irradiation because the alhr2-deleted strain exhibited sensitivity to UV irradiation without showing defects in HR frequency. These results suggest that aLhr1 and aLhr2 are involved in DNA repair in Sulfolobales. Currently, it is not clear whether aLhr2 is involved in the HR process in S. acidocaldarius. Genetic analysis of alhr1 and alhr2 double knockout strains will reveal whether the functions of aLhr1 and aLhr2 in HR overlap.

The structure of aLhr1 has been partially predicted and it is known to have a Cterminal domain containing a Zn-finger-like motif and helix-turn-helix motif (784-911 aa), which are unique to aLhr1 and not present in other Lhr family proteins. The crystal structure of the Mycobacterium smegmatis Lhr core domain (1-856 aa) in complex with AMPPNP, $\mathrm{Mg}^{2+}$, and ssDNA has been elucidated [54]. This domain possesses the helicase and translocase activities, and its structure is conserved in the aLhr2 and Hel308/Hjm from M. thermoautotrophicus [23,55]. These proteins primarily participate in stalled replication fork repair. Since the 3D structure of aLhr1 has not yet been determined, it is difficult to precisely predict the structure-function relationship. However, we speculate that, the unique structural features of the C-terminal domain of aLhr1 might be responsible for its affinity for specific DNA structures. Due to the differences in structure of aLhr1, its affinity towards preferred DNA substrates also varies from other Lhr family helicases. As this study focused on the characterization of SacaLhr1, we did not analyze the SSB protein. However, we think it is important to study on the relationship between SacaLhr1 and SSB are necessary. Future analysis will include the purification of SSB protein from S. acidocaldarius, and physical and functional analysis with SacaLhr1. These experiments will elucidate whether SSB interacts with SacaLhr1 in vitro and whether both proteins colocalize in vivo, and will provide new insights into the molecular mechanism of HR processing by SacaLhr1.

\section{Materials and Methods}

\subsection{Strains and Growth Conditions}

The strains used in this study are listed in Table 1. The S. acidocaldarius strain DP$1(\Delta p y r E \Delta s u a I \Delta p h r)$, in which pyrimidine auxotrophy can be complemented by the selectable marker pyrE [41], was used for the targeted disruption of alhr1. Cultivation and transformation of S. acidocaldarius DP-1 and its derivatives were performed as reported previously [41].

\subsection{Construction of Gene-Deleted Strain}

The plasmids and PCR products used in this study are listed in Table 1. A multiple gene knockout system with one-step PCR (MONSTER) [41] was utilized to prepare the cassette (MONSTER-alhr1) and for construction of the alhr1-deleted strain. In brief, MONSTER-alhr1 was amplified from placSpyrE via PCR using primers MONSTER-alhr1-F (5'-GAAAGAAAGTTTTTAAGAACACGCAAGTACTGGCAGTAAGTTTTTCTCTATATCA ATCTC-3'), comprising a 39-bp target gene (Tg), arm, and a sequence annealed with the lacS marker gene, and MONSTER-alhr1-R (5'-ACCTAACCTAAAAAACAAGAGTTGTATAAA AATATAAACAAACTACATAATAACCTTATTTCTGAGACTCTCCTAGATCTAAAACTAA AG-3'), comprising a 39-bp 3'-flanking region and a 30-bp 5'-flanking region of the alhr 1 gene and a sequence that anneals with the pyrE-maker gene. The amplified DNA fragment was used for transformation.

The transformation protocol for S. acidocaldarius has been previously described in detail [41]. To disrupt the alhr1 gene, $2 \mu \mathrm{g}$ of MONSTER-alhr1 was electroporated into DP-1 cells harvested at the late-log phase. After electroporation, the cells were spread on a selective uracil-free xylose and tryptone (XT) plate medium. After cultivation for $6 \mathrm{~d}$ at 
$75^{\circ} \mathrm{C}$, the transformants grown on the plate were treated with X-gal solution $(10 \mathrm{mg} / \mathrm{mL})$ and were further cultivated at $75^{\circ} \mathrm{C}$ for $1 \mathrm{~d}$. The transformant forming blue colony was isolated, and the genomic DNA was analyzed via PCR using outer primer sets F1/R1 (5'-AATATCCAGTATTAACTAAATAC- ${ }^{\prime}$ ' and 5' -GTTACTAGAACAAAATTACTATC-3') to detect the insertion of MONSTER-alhr1. This intermediate strain was named DP-17 Int $\left(\right.$ pyrE $\left.E^{+} \mathrm{lacS}^{+}\right)$and was used for pop-out recombination. After cultivation on XTUF plate media followed by X-gal visualization, white colonies were selected and analyzed by colony PCR using outer primer sets. The alhr1 gene disruptant ( $\Delta p y r E \Delta s u a I \Delta p h r \Delta a l h r 1)$ was designated as DP-17. The deleted region was confirmed by sequencing using outer primer sets. To confirm the complete deletion of the target gene from the genome, PCR analysis was performed using internal primer sets F2/R2 (5'-ATGATAAGTGTTTCTCAGACATTTATC$3^{\prime}$ and $5^{\prime}$-TTACTGCCAGTACTTGCGTG-3') that were annealed within the alhr1 gene.

\subsection{Estimation of HR Frequencies}

Estimation of HR frequencies was carried out as reported previously [41] with slight modifications. A linear marker cassette, pyrElacS800, harbored approximately 800-bp 5'and $3^{\prime}$-flanking regions of the suaI locus attached to both ends of the pyrE-lacS marker (Table 1). Transformation of competent cells with pyrElacS800 was performed via electroporation. The cells were spread on XT plate media and incubated at $75^{\circ} \mathrm{C}$ for $7-8 \mathrm{~d}$. Transformants were selected using $p y r E^{+}$positive selection. The transformants that presented a blue color by X-gal treatment were assessed as HR-positive. As a control experiment, an autonomously replicating plasmid pSAV2 containing the pyrE selectable marker [40] was used for transformation to calculate the transformation efficiency of each competent cell. The HR frequency and transformation efficiency were defined as the number of positive transformants per $1 \mu \mathrm{g}$ DNA for both assays. Statistical significance was examined using two-tailed Student's $t$-test analysis. Differences were considered statistically significant at $p<0.001$.

\subsection{Cloning of Gene Encoding SacaLhr1 from S. acidocaldarius}

The gene encoding SacaLhr1 was amplified via PCR using S. acidocaldarius DSM639 genomic DNA with the forward primer pET-SacaLhr1-NdeI-F (5'-CGCGCATATGATAAGTGT TTCTCAGACATTTATC- $3^{\prime}$; the NdeI restriction site is underlined) and the reverse primer pET-SacaLhr1-NotI-R (5'-GGGGCGGCCGCTCACTGCCAGTACTTGCGTG-3'; the NotI restriction site is underlined) with PfuDNA polymerase. The amplified fragment was digested with NdeI and NotI and ligated to the corresponding sites of the pET22-28TEV expression vector, which is a modified plasmid of pET28a, wherein the thrombin recognition site and the kanamycin-resistant gene are replaced with a TEV protease recognition site and an ampicillin resistance gene, respectively. The resultant plasmid was designated as pET22-28TEV-SacaLhr1 expressing N-terminal His-tagged SacaLhr1. The nucleotide sequence of the inserted DNA was confirmed via the dideoxy-sequencing method.

\subsection{Preparation of the Recombinant SacaLhr1 Protein}

E. coli C41 (DE3) (Lucigen) is a mutant strain of BL21 (DE3), in which there is a lower expression level of T7 RNA polymerase [56], and this strain is useful for the production of proteins that are toxic to E. coli [57]. E. coli C41 (DE3) was transformed with the pACYC-based plasmid containing extra copies of argU, ile $Y$, and leuW tRNA, in which the chloramphenicol-resistant gene was replaced with the streptomycin-resistant gene, designated as E. coli C41 CodonPlus (DE3)-RIL. This E. coli cell harboring pET22-28TEV-SacaLhr1 were cultured in LB medium containing $50 \mathrm{mg} / \mathrm{L}$ ampicillin and $50 \mathrm{mg} / \mathrm{L}$ streptomycin at $37^{\circ} \mathrm{C}$ until an $\mathrm{OD}_{600}$ value of 0.3 was obtained. IPTG was added to a final concentration of $0.5 \mathrm{mM}$, and the cells were further cultured overnight at $25^{\circ} \mathrm{C}$. The cells were collected, resuspended in $25 \mathrm{~mL}$ buffer A (50 mM Tris- $\mathrm{HCl}, \mathrm{pH} 8.0$, and $1 \mathrm{M} \mathrm{NaCl})$, and sonicated. The soluble cell extract was heated at $70{ }^{\circ} \mathrm{C}$ for $20 \mathrm{~min}$. The heat-resistant fraction was slowly mixed with Ni-NTA agarose (QIAGEN) at $4{ }^{\circ} \mathrm{C}$ for $1 \mathrm{~h}$. The resin was washed with 
buffer A and buffer B ( $50 \mathrm{mM}$ Tris- $\mathrm{HCl}, \mathrm{pH} 8.0$, and $0.15 \mathrm{M} \mathrm{NaCl}$ ), followed by elution of the His-tagged SacaLhr1 with the elution buffer containing $50 \mathrm{mM}$ Tris- $\mathrm{HCl}, \mathrm{pH}$ 8.0, $0.5 \mathrm{M} \mathrm{NaCl}, 0,3 \mathrm{M}$ imidazole, and 10\% glycerol. The fractions containing SacaLhr1 were pooled and subjected to a Hiload $16 / 60$ Superdex $200 \mathrm{pg}$ column (GE Healthcare) with a gel filtration buffer containing $50 \mathrm{mM}$ Tris- $\mathrm{HCl}, \mathrm{pH} 8.0,0.5 \mathrm{M} \mathrm{NaCl}, 0.1 \mathrm{mM}$ EDTA, and $10 \%$ glycerol. Standard marker proteins, including thyroglobulin $(670,000), \gamma$-globulin $(158,000)$, ovalbumin $(44,000)$, and myoglobin $(17,000)$, were subjected to gel filtration as controls. The protein concentration was calculated by measuring the absorbance at $280 \mathrm{~nm}$ using a theoretical molar extinction coefficient of $91,680 \mathrm{M}^{-1} \mathrm{~cm}^{-1}$.

\subsection{ATPase Assay}

The purified SacaLhr1 protein $(225 \mathrm{nM})$ was incubated with $2 \mathrm{mM}$ ATP in a $30-\mu \mathrm{L}$ reaction solution ( $25 \mathrm{mM}$ Tris- $\mathrm{HCl}, \mathrm{pH} 8.0,5 \mathrm{mM} \mathrm{MgCl} 2,50 \mathrm{mM} \mathrm{NaCl}$, and $1 \%$ glycerol) at $60^{\circ} \mathrm{C}$ for 3-12 min in the presence or absence of 2.25-90 $\mu \mathrm{M}$ (mononucleotide) of M13mp18ssDNA and 2.25-90 $\mu \mathrm{M}$ (base pairs) of pUC18. The amounts of Pi in the aliquots were analyzed using an EnzChek Phosphate Assay kit (Invitrogen) according to the manufacturer's protocol. The mean and SD were calculated based on three independent experiments.

\subsection{Preparation of DNA Substrates}

Oligonucleotides used as DNA substrates were obtained from Hokkaido System Science and Sigma-Aldrich and are listed in Table 2. The combinations of oligonucleotides used for the substrates are shown in Table 2. Annealing of the appropriate oligonucleotides was performed in $20 \mathrm{mM}$ Tris- $\mathrm{HCl}(\mathrm{pH} 8.0)$ and $1 \mathrm{mM} \mathrm{MgCl}_{2}$. The mixtures of the oligonucleotides were heated at $98^{\circ} \mathrm{C}$ for $3 \mathrm{~min}$, then gradually cooled to room temperature using a thermal cycler (GeneAtlas G, ASTEC, Kasuya-gun, Fukuoka, Japan), and stored at $4{ }^{\circ} \mathrm{C}$ for subsequent experiments.

\subsection{DNA Unwinding Assay}

DNA unwinding reactions were generally performed in mixtures containing $10 \mathrm{nM}$ substrate and various concentrations of SacaLhr1 proteins. The reaction was quenched by the addition of $25 \mathrm{mM}$ EDTA and $0.1 \%$ SDS. The samples were analyzed by $0.1 \%$ SDS$10 \%$ PAGE in $0.5 \times$ TBE buffer ( $44 \mathrm{mM}$ Tris, $44 \mathrm{mM}$ boric acid and $1.3 \mathrm{mM}$ EDTA, $\mathrm{pH}$ 8.3). The products were visualized with FUSION SOLO.7S.EDGE (Vilber-Lourmat) and quantified using the application software. The SD was calculated from three independent experiments. To determine the unwinding direction of SacaLhr1, $10 \mathrm{nM}^{\prime}$-overhang DNA and 5'-overhang DNA with $15 \mathrm{nM}$ trap DNA (HJ4-34 and H4-34-R, respectively) were incubated with various concentrations of SacaLhr1 $(0,14,28,56,113,225$, and $450 \mathrm{nM}$ as a monomer) in a $15 \mu \mathrm{L}$ reaction mixture $(25 \mathrm{mM}$ Tris- $\mathrm{HCl}, \mathrm{pH}$ 8.0, $1 \mathrm{mM}$ DTT, $2 \mathrm{mM}$ ATP, $5 \mathrm{mM} \mathrm{MgCl}_{2}, 100 \mathrm{mM} \mathrm{NaCl}$, and $2 \%$ glycerol) at $70{ }^{\circ} \mathrm{C}$ for $30 \mathrm{~min}$. For analyses of ATP and $\mathrm{Mg}^{2+}$ dependence, $10 \mathrm{nM}$ splayed DNA1 and $30 \mathrm{nM}$ trap DNA (HJ4-34) were incubated with $225 \mathrm{nM}$ SacaLhr1 in a $15 \mu \mathrm{L}$ reaction mixture $(25 \mathrm{mM}$ Tris- $\mathrm{HCl}, \mathrm{pH} 8.0,1 \mathrm{mM}$ DTT, $50 \mathrm{mM} \mathrm{NaCl}$, and $1 \%$ glycerol) in the presence and absence of various concentrations of ATP and $\mathrm{MgCl}_{2}$ at $60{ }^{\circ} \mathrm{C}$ for the indicated time. To analyze the helicase activity of SacaLhr1 against branch DNA, $10 \mathrm{nM}$ dsDNA, Y-junction2, and HJS were incubated with $123 \mathrm{nM}$ SacaLhr1 in a $15 \mu \mathrm{L}$ reaction mixture $(25 \mathrm{mM}$ Tris- $\mathrm{HCl}, \mathrm{pH}$ 8.0, $1 \mathrm{mM}$ DTT, $1 \mathrm{mM}$ ATP, $5 \mathrm{mM} \mathrm{MgCl}_{2}, 27 \mathrm{mM} \mathrm{NaCl}, 5 \%$ glycerol, and $0.01 \% \mathrm{NP}-40$ ) at $70{ }^{\circ} \mathrm{C}$ for $30 \mathrm{~min}$. To detect intermediate half junctions, $10 \mathrm{nM}$ HJS with $30 \mathrm{nM}$ HJS1-2-trap and HJS2-3-trap were incubated with $225 \mathrm{nM}$ SacaLhr1 in a $15 \mu \mathrm{L}$ reaction mixture $(25 \mathrm{mM}$ Tris- $\mathrm{HCl}, \mathrm{pH} 8.0$, $1 \mathrm{mM}$ DTT, $1 \mathrm{mM}$ ATP, $5 \mathrm{mM} \mathrm{MgCl}$, $50 \mathrm{mM} \mathrm{NaCl}, 1 \%$ glycerol, $5 \%$ PEG4000, and $0.01 \%$ NP-40) at $70{ }^{\circ} \mathrm{C}$ for $30 \mathrm{~min}$. To trap ssDNA, $10 \mathrm{nM} \mathrm{HJ} 2 \mathrm{~S}-\mathrm{RC}$ was used.

\subsection{Electrophoretic Mobility Shift Assay (EMSA)}

Various concentrations $(0,56,113,225$, and $450 \mathrm{nM})$ of SacaLhr1 were incubated with $10 \mathrm{nM}$ ssDNA (5-DyLight 5-HJ2S), dsDNA, splayed DNA2, Y-junction2, and HJS in a $15 \mu \mathrm{L}$ 
reaction mixture (25 mM Tris- $\mathrm{HCl}$, pH 8.0, $1 \mathrm{mM}$ DTT, $5 \mathrm{mM} \mathrm{MgCl}$, $100 \mathrm{mM} \mathrm{NaCl}, 2 \%$ glycerol) at $25{ }^{\circ} \mathrm{C}$ for $10 \mathrm{~min}$, followed by the addition of EMSA buffer (25 mM EDTA, 2.5\% Ficoll, and $0.1 \%$ Orange G). The protein-DNA complexes were fractionated using $1 \%$ (for ssDNA) or $2 \%$ agarose gel in $0.1 \times$ TBE buffer ( $9 \mathrm{mM}$ Tris, $9 \mathrm{mM}$ boric acid, and $0.3 \mathrm{mM}$ EDTA, pH 8.3) and visualized using an image analyzer (FUSION SOLO, Vilber-Lourma).

Supplementary Materials: The following are available online at https:/ / www.mdpi.com/article / 10.3390 / catal12010034/s1, Figure S1: Construction of alhr1-deleted strain using MONSTER, Figure S2: Transformation efficiency and HR frequency.

Author Contributions: Y.I., S.I. and S.S. conceived the project, and each author made substantial contributions to the conception or design of the work, acquisition, analysis, and interpretation of data; S.S. prepared the proteins with the help of T.Y. and performed biochemical analyses with the help of S.I., T.N. and S.M.; Genetic analyses were performed by S.S. with the help of N.K.; S.S. wrote a draft of the manuscript, and S.I. and Y.I. substantively revised it. All authors have read and agreed to the published version of the manuscript.

Funding: This work was supported by a Grant-in-Aid for Japan Society for the Promotion of Science (JSPS) Fellows (JP20J10898 to S.S.) and by JSPS KAKENHI Grant Number JP19K22289 to Y.I. and JP21K05394 to S.I.

Acknowledgments: We thank the Center for Advanced instrumental and Educational Supports (Faculty of Agriculture, Kyushu University) for using an image analyzer.

Conflicts of Interest: The authors claim that there is no conflict of interest.

\section{References}

1. Lindahl, T. Instability and decay of the primary structure of DNA. Nature 1993, 362, 709-715. [CrossRef]

2. Stetter, O.K. Hyperthermophiles in the history of life. Philos. Trans. R. Soc. B Biol. Sci. 2006, 361, 1837-1843. [CrossRef]

3. Grogan, D.W. The question of DNA repair in hyperthermophilic archaea. Trends Microbiol. 2000, 8, 180-185. [CrossRef]

4. Ishino, Y.; Nishino, T.; Morikawa, K. Mechanisms of Maintaining Genetic Stability by Homologous Recombination. Chem. Rev. 2006, 106, 324-339. [CrossRef] [PubMed]

5. White, M.F. Homologous recombination in the archaea: The means justify the ends. Biochem. Soc. Trans. 2011, 39, 15-19. [CrossRef] [PubMed]

6. Grasso, S.; Tell, G. Base excision repair in Archaea: Back to the future in DNA repair. DNA Repair 2014, 21, 148-157. [CrossRef] [PubMed]

7. Grogan, D.W. Understanding DNA repair in hyperthermophilic archaea: Persistent gaps and other reactions to focus on the fork. Archaea 2015, 2015, 942605. [CrossRef]

8. Ishino, Y.; Narumi, I. DNA repair in hyperthermophilic and hyperradioresistant microorganisms. Curr. Opin. Microbiol. 2015, 25, 103-112. [CrossRef]

9. White, M.F.; Allers, T. DNA repair in the archaea-an emerging picture. FEMS Microbiol. Rev. 2018, 42, 514-526. [CrossRef]

10. Craig, J.; Marshall, C.J.; Santangelo, T.J. Archaeal DNA Repair Mechanisms. Biomolecules 2020, 10, 1472.

11. Fujikane, R.; Komori, K.; Shinagawa, H.; Ishino, Y. Identification of a Novel Helicase Activity Unwinding Branched DNAs from the Hyperthermophilic Archaeon, Pyrococcus furiosus. J. Biol. Chem. 2005, 280, 12351-12358. [CrossRef]

12. Guy, C.P.; Bolt, E.L. Archaeal Hel308 helicase targets replication forks in vivo and in vitro and unwinds lagging strands. Nucleic Acids Res. 2005, 33, 3678-3690. [CrossRef]

13. Fujikane, R.; Shinagawa, H.; Ishino, Y. The archaeal Hjm helicase has recQ-like functions, and may be involved in repair of stalled replication fork. Genes Cells 2006, 11, 99-110. [CrossRef]

14. Tsuboi, K.; Sakai, H.D.; Nur, N.; Stedman, K.M.; Kurosawa, N.; Suwanto, A. Sulfurisphaera javensis sp. nov., a hyperther-mophilic and acidophilic archaeon isolated from Indonesian hot spring, and reclassification of Sulfolobus tokodaii Suzuki et al. 2002 as Sulfurisphaera tokodaii comb. nov. Int. J. Syst. Evol. Microbiol. 2018, 68, 1907-1913. [CrossRef]

15. Li, Z.; Lu, S.; Hou, G.; Ma, X.; Sheng, D.; Ni, J.; Shen, Y. Hjm/Hel308A DNA helicase from Sulfolobus tokodaii promotes repli-cation fork regression and interacts with Hjc endonuclease in vitro. J. Bacteriol. 2008, 190, 3006-3017. [CrossRef]

16. Zhai, B.; Duprez, K.; Doukov, T.I.; Li, H.; Huang, M.; Shang, G.; Ni, J.; Gu, L.; Shen, Y.; Fan, L. Structure and function of a novel ATPase that interacts with holloday junction resolvase Hjc and promotes branch migration. J. Mol. Biol. 2017, 429, 1009-1029. [CrossRef]

17. Yamada, K.; Miyata, T.; Tsuchiya, D.; Oyama, T.; Fujiwara, Y.; Ohnishi, T.; Iwasaki, H.; Shinagawa, H.; Ariyoshi, M.; Ma-yanagi, K.; et al. Crystal structure of the RuvA-RuvB complex: A structural basis for the Holliday junction migrating motor machinery. Mol. Cell 2002, 10, 671-681. [CrossRef] 
18. Zhai, B.; DuPrez, K.; Han, X.; Yuan, Z.; Ahmad, S.; Xu, C.; Gu, L.; Ni, J.; Fan, L.; Shen, Y. The archaeal ATPase PINA interacts with the helicase Hjm via its carboxyl terminal $\mathrm{KH}$ domain remodeling and processing replication fork and Holliday junction. Nucleic Acids Res. 2018, 46, 6627-6641. [CrossRef] [PubMed]

19. Reuven, N.B.; Koonin, E.V.; Rudd, E.K.; Deutscher, M.P. The gene for the longest known Escherichia coli protein is a member of helicase superfamily II. J. Bacteriol. 1995, 177, 5393-5400. [CrossRef] [PubMed]

20. Ordonez, H.; Shuman, S. Mycobacterium smegmatis Lhr is a DNA-dependent ATPase and a $3^{\prime}$-to- $5^{\prime}$ DNA Translocase and Helicase That Prefers to Unwind 3'-Tailed RNA:DNA Hybrids. J. Biol. Chem. 2013, 288, 14125-14134. [CrossRef]

21. De Felice, M.; Aria, V.; Esposito, L.; De Falco, M.; Pucci, B.; Rossi, M.; Pisani, F.M. A novel DNA helicase with strand-annealing activity from the crenarchaeon Sulfolobus solfataricus. Biochem. J. 2007, 408, 87-95. [CrossRef] [PubMed]

22. van Wolferen, M.; Ma, X.; Albers, S.-V. DNA Processing Proteins Involved in the UV-Induced Stress Response of Sulfolobales. J. Bacteriol. 2015, 197, 2941-2951. [CrossRef] [PubMed]

23. Buckley, R.J.; Kramm, K.; Cooper, C.D.O.; Grohmann, D.; Bolt, E.L. Mechanistic insights into Lhr helicase function in DNA repair. Biochem. J. 2020, 477, 2935-2947. [CrossRef]

24. Chamieh, H.; Ibrahim, H.; Kozah, J. Genome-wide identification of SF1 and SF2 helicases from archaea. Gene 2016, 576, 214-228. [CrossRef]

25. Hajj, M.; Langendijk-Genevaux, P.; Batista, M.; Quentin, Y.; Laurent, S.; Abdel Razzak, Z.; Flament, D.; Chamieh, H.; Fichant, G.; Clouet-d'Orval, B.; et al. Phylogenetic Diversity of Lhr Proteins and Biochemical Activities of the Thermococcales aLhr2 DNA/RNA Helicase. Biomolecules 2021, 11, 950. [CrossRef]

26. Murzin, A.G. OB(oligonucleotide/oligosaccharide binding)-fold: Common structural and functional solution for non-homologous sequences. EMBO J. 1993, 12, 861-867. [CrossRef]

27. Chédin, F.; Seitz, E.M.; Kowalczykowski, S.C. Novel homologs of replication protein A in Archaea: Implications of the evolution of ssDNA-binding proteins. Trends Biochem. Sci. 1998, 23, 273-277. [CrossRef]

28. Kerr, I.D.; Wadsworth, R.I.; Cubeddu, L.; Blankenfeldt, W.; Naismith, J.H.; White, M. Insights into ssDNA recognition by the OB fold from a structural and thermodynamic study of Sulfolobus SSB protein. EMBO J. 2003, 22, 2561-2570. [CrossRef]

29. Paytubi, S.; McMahon, S.A.; Graham, S.; Liu, H.; Botting, C.H.; Makarova, K.S.; Koonin, E.V.; Naismith, J.H.; White, M.F. Displacement of the canonical single-stranded DNA-binding protein in the Thermoproteales. Proc. Natl. Acad. Sci. USA 2012, 109, E398-E405. [CrossRef]

30. Meyer, R.R.; Glassberg, J.; Kornberg, A. An Escherichia coli mutant defective in single-strand binding protein is defective in DNA replication. Proc. Natl. Acad. Sci. USA 1979, 76, 1702-1705. [CrossRef] [PubMed]

31. Glassberg, J.; Meyer, R.R.; Kornberg, A. Mutant single-strand binding protein of Escherichia coli: Genetic and physiological characterization. J. Bacteriol. 1979, 140, 14-19. [CrossRef]

32. Longhese, M.P.; Plevani, P.; Lucchini, G. Replication factor A is required in vivo for DNA replication, repair, and recombination. Mol. Cell. Biol. 1994, 14, 7884-7890.

33. Muniyappa, K.; Shaner, S.L.; Tsang, S.S.; Radding, C.M. Mechanism of the concerted action of recA protein and he-lix-destabilizing proteins in homologous recombination. Proc. Natl. Acad. Sci. USA 1984, 81, 2757-2761. [CrossRef]

34. Sugiyama, T.; Zaitseva, E.M.; Kowalczykowski, S.C. A single-stranded DNA-binding protein is needed for efficient presynaptic complex formation by the Saccharomyces cerevisiae Rad51 protein. J. Biol. Chem. 1997, 272, 7940-7945. [CrossRef]

35. Komori, K.; Ishino, Y. Replication Protein A in Pyrococcus furiosus Is Involved in Homologous DNA Recombination. J. Biol. Chem. 2001, 276, 25654-25660. [CrossRef]

36. Haseltine, C.A.; Kowalczykowski, S.C. A distinctive single-stranded DNA-binding protein from the Archaeon Sulfolobus solfataricus. Mol. Microbiol. 2002, 43, 1505-1515. [CrossRef]

37. Rolfsmeier, M.L.; Haseltine, C.A. The Single-Stranded DNA Binding Protein of Sulfolobus solfataricus Acts in the Presynaptic Step of Homologous Recombination. J. Mol. Biol. 2010, 397, 31-45. [CrossRef]

38. Wei, T.; Zhang, S.; Zhu, S.; Sheng, D.; Ni, J.; Shen, Y. Physical and functional interaction between archaeal single-stranded DNA-binding protein and the 5'-3' nuclease NurA. Biochem. Biophys. Res. Commun. 2008, 367, 523-529. [CrossRef] [PubMed]

39. Cubeddu, L.; White, M.F. DNA Damage Detection by an Archaeal Single-stranded DNA-binding Protein. J. Mol. Biol. 2005, 353, 507-516. [CrossRef] [PubMed]

40. Suzuki, S.; Kurosawa, N. Disruption of the gene encoding restriction endonuclease SuaI and development of a host-vector system for the thermoacidophilic archaeon Sulfolobus acidocaldarius. Extremophiles 2016, 20, 139-148. [CrossRef] [PubMed]

41. Suzuki, S.; Kurosawa, N. Development of the multiple gene knockout system with one-step PCR in thermophilic crenarchaeon Sulfolobus acidocaldarius. Archaea 2017, 2017, 7459310. [CrossRef]

42. Ogino, H.; Ishino, S.; Haugland, G.T.; Birkeland, N.K.; Kohda, D.; Ishino, Y. Activation of the MCM helicase from the thermophilic archaeon, Thermoplasma acidophilum by interactions with GINS and Cdc6-2. Extremophiles 2014, 18, 915-924. [CrossRef]

43. Muris, D.F.R.; Vreeken, K.; Schmidt, H.; Ostermann, K.; Clever, B.; Lohman, P.H.M.; Pastink, A. Homologous recombination in the fission yeast Schizosaccharomyces pombe: Different requirements for the rhp51+, rhp54 + and rad22 + genes. Curr. Genet. 1997, 31, 248-254. [CrossRef]

44. Tsutsui, Y.; Morishita, T.; Iwasaki, H.; Toh, H.; Shinagawa, H. A Recombination Repair Gene of Schizosaccharomyces pombe, rhp57, Is a Functional Homolog of the Saccharomyces cerevisiae RAD57 Gene and Is Phylogenetically Related to the Human XRCC3 Gene. Genetics 2000, 154, 1451-1461. [CrossRef] 
45. Woods, W.G.; Dyall-Smith, M.L. Construction and analysis of a recombination-deficient (radA) mutant of Haloferax volcan-ii. Mol. Microbiol. 1997, 23, 791-797. [CrossRef] [PubMed]

46. Nimonkar, A.V.; Özsoy, A.Z.; Genschel, J.; Modrich, P.; Kowalczykowski, S.C. Human exonuclease 1 and BLM helicase interact to resect DNA and initiate DNA repair. Proc. Natl. Acad. Sci. USA 2008, 105, 16906-16911. [CrossRef]

47. Nimonkar, A.V.; Genschel, J.; Kinoshita, E.; Polaczek, P.; Campbell, J.L.; Wyman, C.; Modrich, P.; Kowalczykowski, S.C. BLMDNA2-RPA-MRN and EXO1-BLM-RPA-MRN constitute two DNA end resection machineries for human DNA break repair. Genes Dev. 2011, 25, 350-362. [CrossRef] [PubMed]

48. De Falco, M.; Catalano, F.; Rossi, M.; Ciaramella, M.; De Felice, M. NurA Is Endowed with Endo- and Exonuclease Activities that Are Modulated by HerA: New Insight into Their Role in DNA-End Processing. PLoS ONE 2015, 10, e0142345. [CrossRef] [PubMed]

49. De Falco, M.; Massa, F.; Rossi, M.; De Felice, M. The Sulfolobus solfataricus RecQ-like DNA helicase Hel112 inhibits the Nu-rA/HerA complex exonuclease activity. Extremophiles 2018, 22, 581-589. [CrossRef] [PubMed]

50. Hishida, T.; Han, Y.-W.; Shibata, T.; Kubota, Y.; Ishino, Y.; Iwasaki, H.; Shinagawa, H. Role of the Escherichia coli RecQ DNA helicase in SOS signaling and genome stabilization at stalled replication forks. Genes Dev. 2004, 18, 1886-1897. [CrossRef] [PubMed]

51. Ejaz, A.; Shuman, S. Characterization of Lhr-Core DNA helicase and manganese- dependent DNA nuclease components of a bacterial gene cluster encoding nucleic acid repair enzymes. J. Biol. Chem. 2018, 293, 17491-17504. [CrossRef]

52. Warren, G.M.; Wang, J.; Patel, D.J.; Shuman, S. Oligomeric quaternary structure of Escherichia coli and Mycobacterium smegmatis Lhr helicases is nucleated by a novel C-terminal domain composed of five winged-helix modules. Nucleic Acids Res. 2021, 49, 3876-3887. [CrossRef]

53. Song, X.; Huang, Q.; Ni, J.; Yu, Y.; Shen, Y. Knockout and functional analysis of two DExD/H-box family helicase genes in Sulfolobus islandicus REY15A. Extremophiles 2016, 20, 537-546. [CrossRef] [PubMed]

54. Ejaz, A.; Ordonez, H.; Jacewicz, A.; Ferrao, R.; Shuman, S. Structure of mycobacterial 3'-to-5' RNA:DNA helicase Lhr bound to a ssDNA tracking strand highlights distinctive features of a novel family of bacterial helicases. Nucleic Acids Res. 2018, 46, 442-455. [CrossRef] [PubMed]

55. Büttner, K.; Nehring, S.; Hopfner, K.-P. Structural basis for DNA duplex separation by a superfamily-2 helicase. Nat. Struct. Mol. Biol. 2007, 14, 647-652. [CrossRef]

56. Schlegel, S.; Genevaux, P.; de Gier, J.-W. De-convoluting the Genetic Adaptations of E. coli C41(DE3) in Real Time Reveals How Alleviating Protein Production Stress Improves Yields. Cell Rep. 2015, 10, 1758-1766. [CrossRef] [PubMed]

57. Dumon-Seignovert, L.; Cariot, G.; Vuillard, L. The toxicity of recombinant proteins in Escherichia coli: A comparison of overexpression in BL21(DE3), C41(DE3), and C43(DE3). Protein Expr. Purif. 2004, 37, 203-206. [CrossRef] 